\title{
Prevention of diabetes-associated fibrosis : Strategies in FcRn-targeted nanosystems for oral drug delivery
}

\section{Azevedo, Cláudia}

2021-08

Azevedo , C, Pinto , S , Benjakul , S, Nilsen , J , Santos , H A , Traverso , G , Andersen , J

T \& Sarmento , B 2021 , ' Prevention of diabetes-associated fibrosis : Strategies in

FcRn-targeted nanosystems for oral drug delivery ', Advanced Drug Delivery Reviews , vol.

175 , 113778 . https://doi.org/10.1016/j.addr.2021.04.016

http://hdl.handle.net/10138/333029

https://doi.org/10.1016/j.addr.2021.04.016

acceptedVersion

Downloaded from Helda, University of Helsinki institutional repository.

This is an electronic reprint of the original article.

This reprint may differ from the original in pagination and typographic detail.

Please cite the original version. 


\section{Journal Pre-proofs}

Prevention of diabetes-associated fibrosis: Strategies in FcRn-targeted nanosystems for oral drug delivery

Cláudia Azevedo, Soraia Pinto, Sopisa Benjakul, Jeannette Nilsen, Hélder A. Santos, Giovanni Traverso, Jan Terje Andersen, Bruno Sarmento

PII: S0169-409X(21)00116-2

DOI: https://doi.org/10.1016/j.addr.2021.04.016

Reference: ADR 13778

To appear in: Advanced Drug Delivery Reviews

Received Date: 19 January 2021

Revised Date: 29 March 2021

Accepted Date: 16 April 2021

Please cite this article as: C. Azevedo, S. Pinto, S. Benjakul, J. Nilsen, H.A. Santos, G. Traverso, J. Terje Andersen, B. Sarmento, Prevention of diabetes-associated fibrosis: Strategies in FcRn-targeted nanosystems for oral drug delivery, Advanced Drug Delivery Reviews (2021), doi: https://doi.org/10.1016/j.addr.2021.04.016

This is a PDF file of an article that has undergone enhancements after acceptance, such as the addition of a cover page and metadata, and formatting for readability, but it is not yet the definitive version of record. This version will undergo additional copyediting, typesetting and review before it is published in its final form, but we are providing this version to give early visibility of the article. Please note that, during the production process, errors may be discovered which could affect the content, and all legal disclaimers that apply to the journal pertain.

(C) 2021 Elsevier B.V. All rights reserved. 


\title{
Prevention of diabetes-associated fibrosis: Strategies in FcRn-targeted nanosystems for oral drug delivery
}

\author{
Cláudia Azevedo1,2,\#, Soraia Pinto1,2,\#, Sopisa Benjakul3,4,\#, Jeannette Nilsen ${ }^{3,4}$, Hélder A. \\ Santos $^{5,6}$, Giovanni Traverso ${ }^{7,8,9}$, Jan Terje Andersen ${ }^{3,4,}{ }^{*}$, Bruno Sarmento ${ }^{1,10,{ }^{*}}$
}

\footnotetext{
${ }^{1}$ Instituto de Investigação e Inovação em Saúde (i3S), University of Porto, Rua Alfredo Allen, 208, 4200135 Porto, Portugal.

2 Instituto de Ciências Biomédicas Abel Salazar (ICBAS), University of Porto, Rua Jorge Viterbo Ferreira, 228, 4150-180 Porto, Portugal.

${ }^{3}$ Department of Immunology, Oslo University Hospital Rikshospitalet and University of Oslo, N-0424 Oslo, Norway.

${ }^{4}$ Institute of Clinical Medicine and Department of Pharmacology, University of Oslo and Oslo University Hospital, 0372 Oslo, Norway.

${ }^{5}$ Drug Research Program, Division of Pharmaceutical Chemistry and Technology, Faculty of Pharmacy, University of Helsinki, Fl-00014 Helsinki, Finland.

${ }^{6}$ Helsinki Institute of Life Science (HiLIFE), University of Helsinki, FI-00014 Helsinki, Finland.

7 Department of Chemical Engineering and Koch Institute for Integrative Cancer Research, Massachusetts Institute of Technology, 02139 Cambridge, MA, USA.

8 Division of Gastroenterology, Brigham and Women's Hospital, Harvard Medical School, 02115 Boston, MA, USA.

${ }^{9}$ Department of Mechanical Engineering, Massachusetts Institute of Technology, 02139 Cambridge, MA, USA.

${ }^{10}$ CESPU, Instituto de Investigação e Formação Avançada em Ciências e Tecnologias da Saúde \& Instituto Universitário de Ciências da Saúde, 4585-116 Gandra, Portugal.

\# Cláudia Azevedo, Soraia Pinto and Sopisa Benjakul contributed equally.

*Corresponding authors: bruno.sarmento@ineb.up.pt and j.t.andersen@medisin.uio.no
}

\footnotetext{
Abbreviations

ABD, albumin-binding domain; AGEs, advanced glycation end-products; BSA, bovine serum albumin; $\mathbf{\beta 2 m}$, beta-2 microglobulin; DM, diabetes mellitus; DPP-4, dipeptidyl peptidase-4; ECM, extracellular matrix; EDC/NHS, 1-ethyl-3-(3-dimethylaminopropyl)-carbodiimide/N-hydroxysuccinimide; Fab, fragment antigen-binding; Fc, fragment crystallizable; Fc-NPs, Fc-decorated nanoparticles; FcRn, neonatal Fc receptor; FcRnBPs, neonatal Fc receptorbinding peptides; GIT, gastrointestinal tract; GLP-1, glucagon-like peptide-1; hFcRn, human neonatal Fc receptor; hIgG, human immunoglubulin G; HPMC, hypromellose acetate succinate; HSA, human serum albumin; HSA-NPs, HSA-decorated nanoparticles; IgG, immunoglobulin G; MAL, maleimide; mFcRn, mouse neonatal Fc receptor; MHC-I, major histocompatibility complex class I; mIgG, mouse immunoglubulin G; MSA, mouse serum albumin, NPs, nanoparticles; OI, Oral insulin, PEG, polyethylene glycol; PLA, poly(lactic acid); PLGA, poly(lactic-co-glycolic acid); RAAS, renin-angiotensinaldosterone system; scFv, single-chain variable fragment; SiNPs, silica nanoparticles; T1DM, type 1 diabetes mellitus; T2DM, type 2 diabetes mellitus; TGF- $\beta$, transforming growth factor beta; $\mathbf{W T}$, wild-type.
} 
Abstract

Diabetes mellitus is a chronic disease with an elevated risk of micro- and macrovascular complications, such as fibrosis. To prevent diabetes-associated fibrosis, the symptomatology of diabetes must be controlled, which is commonly done by subcutaneous injection of antidiabetic peptides. To minimize the pain and distress associated with such injections, there is an urgent need for non-invasive oral transmucosal drug delivery strategies. However, orally administered peptide-based drugs are exposed to harsh conditions in the gastrointestinal tract and poorly cross the selective intestinal epithelium. Thus, targeting of drugs to receptors expressed in epithelial cells, such as the neonatal Fc receptor (FcRn), may therefore enhance uptake and transport through mucosal barriers. This review compiles how in-depth studies of FcRn biology and engineering of receptor-binding molecules may pave the way for design of new classes of FcRn-targeted nanosystems. Tailored strategies may open new avenues for oral drug delivery and provide better treatment options for diabetes and, consequently, fibrosis prevention.

Keywords: Antidiabetic peptides, FcRn, IgG, albumin, intestinal epithelium, transcytosis, halflife, nanoparticles, active targeting, transgenic mouse model.

Teaser: This review provides a brief overview of FcRn biology, engineering of receptor-binding molecules, and recent advances in FcRn-targeted nanosystems with the aim of improving oral drug transport of antidiabetic peptides across selective intestinal epithelial barriers for the treatment of diabetes mellitus and, consequently, prevention of fibrosis.

\section{Graphical abstract:}

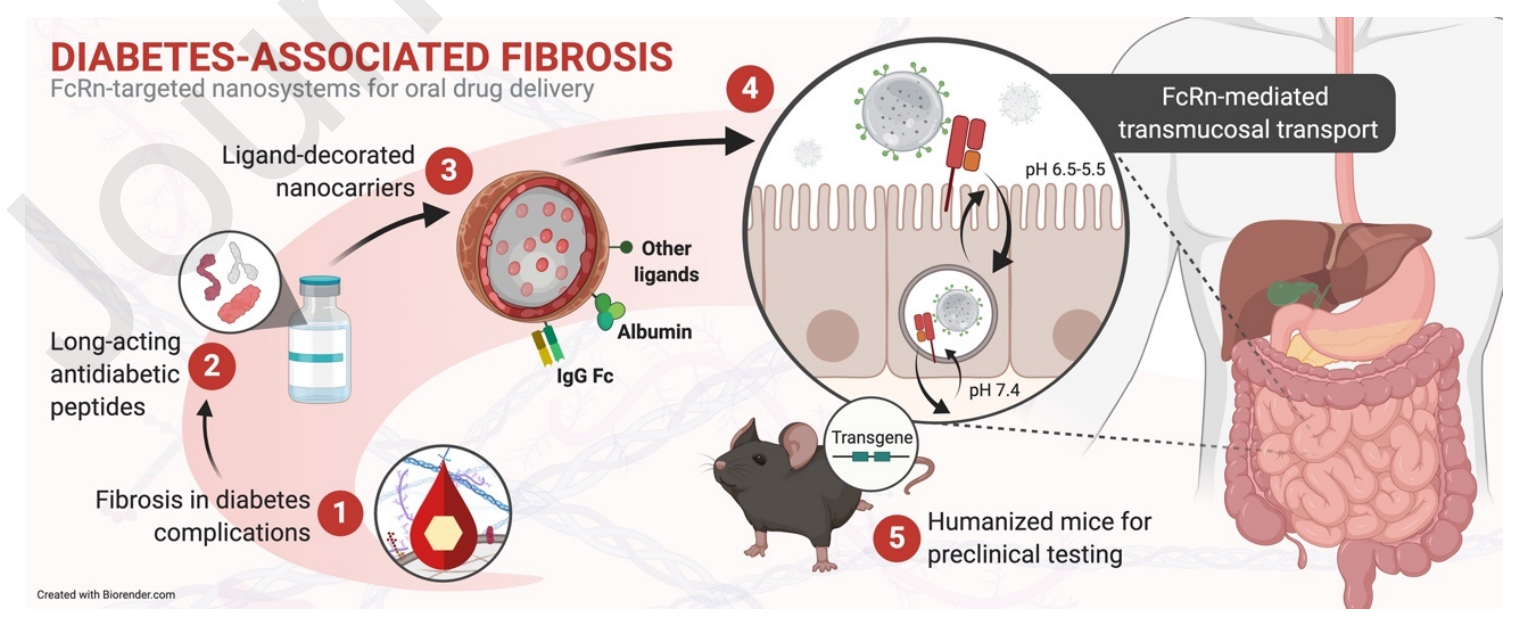


Table of contents

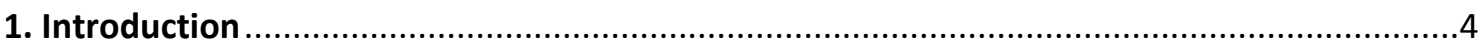

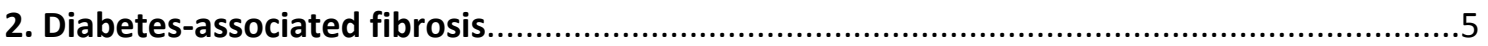

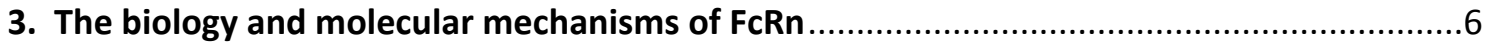

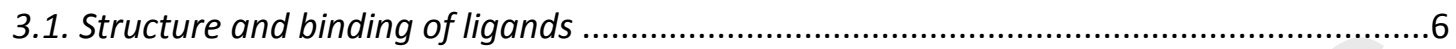

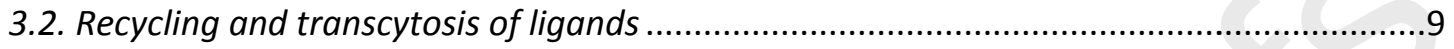

4. IgG- and albumin-based drug delivery of antidiabetic peptides ........................................11

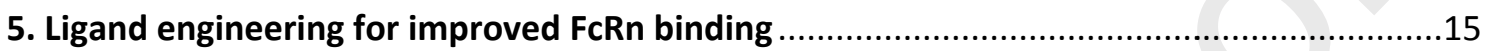

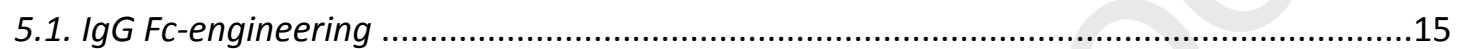

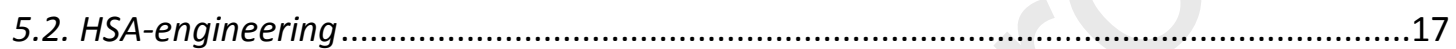

5.3. Alternative engineered FcRn-binding scaffolds ..........................................................19

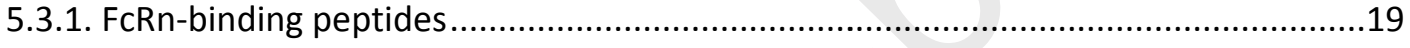

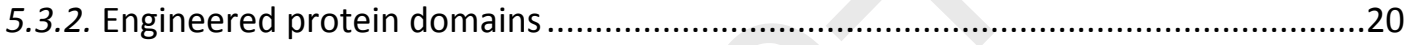

6. The importance of considering cross-species FcRn differences for preclinical evaluation ..21

6.1. Biology of FCRn and its ligand in mice and humans ...................................................22

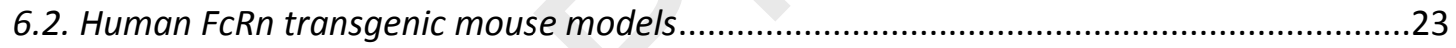

7. FcRn-targeted nanosystems for oral delivery of antidiabetic peptides.............................26

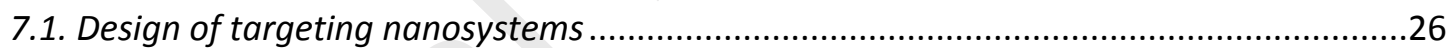

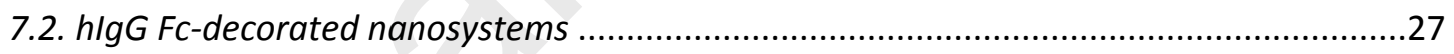

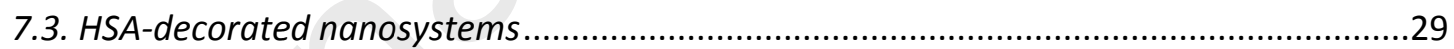

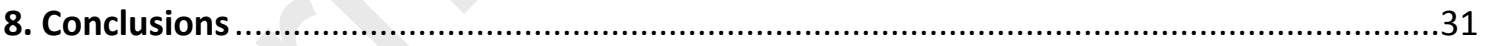

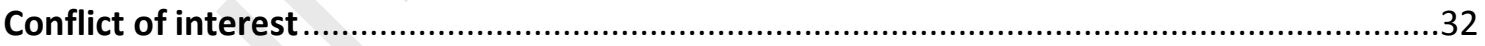

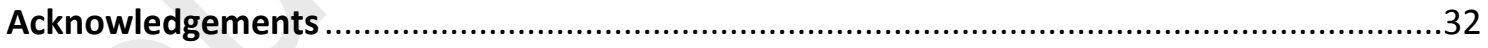

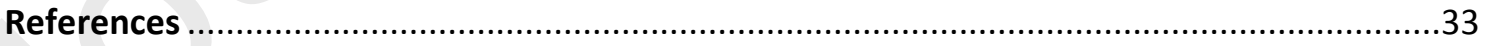




\section{Introduction}

Diabetes mellitus (DM) is a chronic metabolic disease that develops when the pancreas fails to produce insulin or when the body does not fully respond to insulin, leading to impaired glucose tolerance. More than 460 million people worldwide are suffering from DM, and the number of cases is predicted to rise to 700 million by $2045[1,2]$. Prolonged exposure to hyperglycemia may cause tissue injury and lead to fibrosis, which increases the risk of micro- and macrovascular complications in several organs, such as the eyes (diabetic retinopathy), kidneys (diabetic nephropathy), skin, heart, liver, lungs, nerves (neuropathy) and blood vessels (angiopathy) [3, 4]. Fibrosis is characterized by abnormal deposition of the extracellular matrix (ECM), and there is currently no specific treatment available [5]. As such, there is an urgent need for strategies that could prevent or delay the progression of diabetes-associated fibrosis.

Conventional treatment of DM requires subcutaneous injection of peptide-based antidiabetic drugs for glycemic control, which is considered a painful and invasive approach. The preferred route of administration is oral delivery via mucosal surfaces, due to its ease of administration and high patient compliance, without the need for syringes, needles, and trained health workers $[6,7]$. Notwithstanding, orally administered antidiabetic peptides are susceptible to the harsh environment of the gastrointestinal tract (GIT) and the selective barrier of the intestinal epithelium [8, 9]. Hence, there is a demand for innovative strategies to overcome these limitations.

Biodegradable and biocompatible nanoparticles (NPs) have emerged as promising oral drug delivery systems that protect encapsulated drugs from acidic $\mathrm{pH}$ and enzymatic degradation in the GIT, while also providing controlled and sustained release and enhanced bioavailability of drugs to target sites. However, the transport of NPs across intestinal mucosa is restricted by polarized epithelial cell layers $[8,10]$. Several recent studies support that targeting of the neonatal Fc receptor ( $\mathrm{FCRn})$, which is expressed by such epithelial cells and mediates bidirectional transport and recycling of immunoglobulin $\mathrm{G}(\mathrm{IgG})$ and albumin, may be used as a gateway for more efficient transcellular transport of NPs [11-15]. Furthermore, in light of successes in the development of engineered ligands and alternative scaffolds with improved FcRn binding and transport properties, researchers may now harvest from these advances in the design of new classes of NPs decorated with FcRn-targeted molecules, with the aim of enhancing transmucosal delivery upon oral administration. This review provides a brief overview of FcRn biology and discusses how receptor-binding molecules may be incorporated into nanosystems for improved FcRn-mediated oral delivery of antidiabetic peptides for the treatment of DM and the prevention of fibrosis. 


\section{Diabetes-associated fibrosis}

Fibrosis is one of the major complications of DM, induced by chronic hyperglycemia, which leads to an excessive accumulation of ECM macromolecules and an imbalance in tissue homeostasis $[3,5]$. Normally, ECM is responsible for the mechanical and structural support of cells and mediates intercellular communication. However, under cell and tissue injury, the formation of ECM is dysregulated. This is a complex and multifactorial process involving increased production of advanced glycation end-products (AGEs) and circulating growth factors, and activation of protein kinase $C$ as well as the renin-angiotensin-aldosterone system (RAAS) and plasminogen and protease systems $[3,16]$. A schematic overview of fibrosis development as a result of diabetes-induced hyperglycemia is shown in Fig. 1.

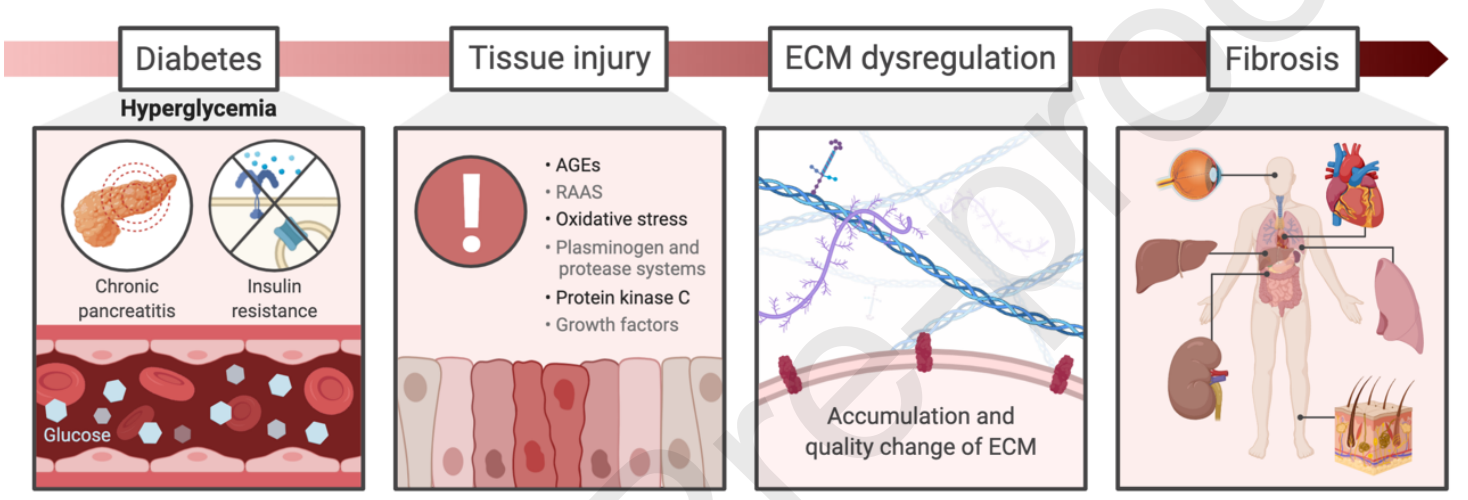

Fig. 1 | Fibrosis as a complication of diabetes. In DM, impaired pancreatic function or insulin resistance causes blood glucose levels to rise above normal. Prolonged hyperglycemic condition may induce severe tissue injury by the action of AGEs, RAAS, oxidative stress, plasminogen and protease systems, protein kinase $\mathrm{C}$ and circulating growth factors. This leads to dysregulation of the ECM, characterized by excessive accumulation of ECM components and alteration in ECM quality, which triggers the formation of fibrosis in several organs. The figure was created with BioRender.

AGEs are lipids or proteins that are glycated upon exposure to sugars, which are prevalent in patients with DM. Under hyperglycemic conditions, AGEs stimulate the excess production of ECM macromolecules, which affects the ECM integrity and the profibrotic process $[3,5]$. RAAS, in which angiotensin II is considered the main effector molecule, promotes the accumulation of ECM components as well as the release of inflammatory cytokines and growth factors, such as transforming growth factor beta (TGF- $\beta$ ), vascular endothelial growth factor, platelet-derived growth factor, and connective tissue growth factor $[3,5]$. In addition, oxidative stress can accelerate the progression of fibrosis [2]. In particular, the increase in TGF- $\beta$ stimulates the epithelial-to-mesenchymal transition, which contributes to the accumulation of ECM components, culminating in tissue fibrosis $[17,18]$. 
Interestingly, antidiabetic peptides have great potential in the treatment of fibrosis. For instance, dipeptidyl peptidase-4 (DDP-4) inhibitors, known as gliptins, and glucagon-like peptide 1 (GLP-1) agonists, have demonstrated mild antifibrotic properties in models of liver fibrosis by reducing inflammation and oxidative stress [19]. Owning to the antidiabetic activity of gliptins and GLP-1 analogs, they are widely used in the treatment of type 2 diabetes (T2DM) [20]. Furthermore, encapsulation of these peptide-based drugs into nanosystems targeting FcRn, by taking advantage of the protective effect of NPs and receptor-targeting ligands with improved FcRn binding and transport properties, may lead to enhanced transmucosal delivery upon oral administration. In addition, these antidiabetic peptides may be engineered for half-life extension using FcRn-binding molecules. Notably, FcRn is expressed by cells of the lungs, eyes and kidneys [21-23], where fibrosis typically occurs.

\section{The biology and molecular mechanisms of FcRn}

\subsection{Structure and binding of ligands}

FcRn is a heterodimeric glycoprotein that is structurally similar to major histocompatibility complex class I (MHC-I) molecules, consisting of a unique transmembrane heavy chain (40-46 $\mathrm{kDa}$ ) that is non-covalently associated with the common beta-2-microglobulin $(\beta 2 \mathrm{~m})$ light chain $(12 \mathrm{kDa})[24,25]$. The heavy chain contains three extracellular domains (denoted $\alpha 1, \alpha 2$ and $\alpha 3$ ) where the $\alpha 1$ and $\alpha 2$ domains assemble a platform of eight antiparallel $\beta$-strands topped by two $\alpha$-helices followed by the $\alpha 3$ domain, which is folded up on the soluble $\beta 2 m[26,27]$.

Unlike MHC-I molecules that present antigenic peptides via their peptide binding groove to cytotoxic T cells, the corresponding binding groove of FcRn is closed [26-29]. Instead, FcRn has evolved to bind IgG and albumin, two structurally and functionally unrelated proteins. Both ligands bind the receptor in a pH-dependent manner, binding at acidic $\mathrm{pH}$ (6.5-5-0) and no binding or release at physiological pH (7.4) [30-35]. The strict pH-dependent mode of action is mediated by protonation of the imidazole side chains of conserved histidine residues found on both the receptor and the ligands. When the $\mathrm{pH}$ increases towards neutral, protonation of the histidine residues is gradually lost, and the ligands are released from the receptor [31, 33, 34, 36, 37]. Importantly, FcRn binds both ligands simultaneously in a non-cooperative manner as a ternary complex (Fig. 2) [32, 35, 37]. 


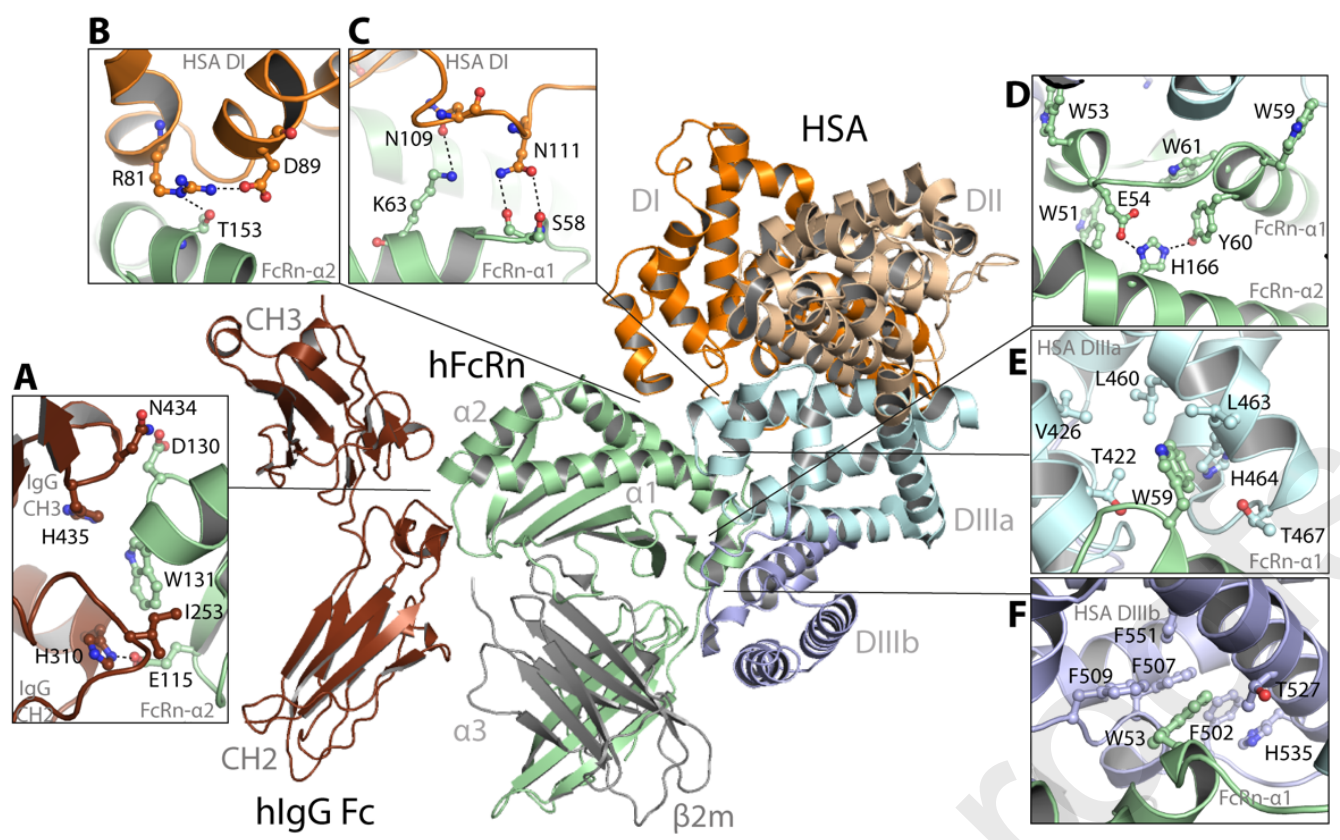

Fig. 2 | Crystallographic illustration of the ternary complex of hFcRn bound to hlgG and HSA. The three domains of the hFcRn heavy chain (denoted $\alpha 1, \alpha 2$, and $\alpha 3$ ) are shown in green, and the $\beta 2 \mathrm{~m}$ subunit in gray. The hIgG1 Fc fragment is shown in brown. The subdomains DI, DII, DIIla and DIIlb of HSA are colored in orange, wheat, light cyan and light blue, respectively. (A) Close-ups showing key amino acid residues involved in the interaction between hlgG1 (H310, I253, H435, N434) and hFcRn (E115, W131, D130). (B and C) Close-ups of the interactions between two loops in DI of HSA (loop I; R81, D89, and loop II; N109, N111) and hFcRn (T153, K63, S58). (D) Close-ups of the intramolecular interactions between H166 of the $\alpha 2$ domain and $\mathrm{E} 54$ and $\mathrm{Y} 60$ of the $\alpha 1$ domain in $\mathrm{hFcRn}$, which form at acidic $\mathrm{pH}$ and in turn stabilize the loop containing W51, W53, W59 and W61. (E and F) Close-ups showing W59 and W53 of hFcRn inserted into hydrophobic pockets in DIIla (T422, V426, L460, L463, H464 and T467) and DIIIb (F502, F507, F509, T527 and F551) of HSA, respectively. The figure was made using PyMol and the crystal structure data deposited of hFcRn bound to hIgG1 Fc and HSA (PDB 4NOU) [35].

$\operatorname{lgG}(150 \mathrm{kDa})$ is the most prevalent antibody in blood, with concentrations ranging from 2-14 $\mathrm{mg} / \mathrm{mL}$ in mice, and $8-17 \mathrm{mg} / \mathrm{mL}$ in humans [38-42]. It is produced by $B$ and plasma cells and protects the body from foreign substances, such as pathogens and toxins. This Y-shaped homodimeric protein contains four polypeptides that make up two fragment antigen-binding (Fab) arms, linked via a hinge to a constant $\mathrm{N}$-glycosylated fragment crystallizable $(\mathrm{Fc})$ part [38, $43,44]$. While the Fab arms recognize foreign antigens, the Fc is responsible for binding to effector molecules, including FcRn [38, 43]. The interaction between FcRn and IgG occurs primarily at the $\mathrm{CH} 2-\mathrm{CH} 3$ elbow region with a stoichiometry of two FcRn molecules per monomeric IgG, where the conserved residues I253, H310 and H435 are key players [27, 35, 45- 
50]. Specifically, protonation of the histidine residue $\mathrm{H} 310$ at acidic $\mathrm{pH}$ enables interaction with E115 on the $\alpha 2$-domain of the human FcRn ( $\mathrm{hFcRn}$ ) heavy chain $[35,50]$. Moreover, 1253 interacts with W131 of the receptor, whereas the side chain of $\mathrm{H} 435$ does not make any direct contacts but has been shown to regulate a loop within the Fc, including residues 429-436, prior to binding $[27,35,50,51]$. Replacement of these residues with alanine abrogates receptor binding, and results in inefficient transport and short half-life [22, 46, 49, 50, 52-54]. Also, the soluble $\beta 2 \mathrm{~m}$ of rat FcRn has been shown to contribute to binding of rat IgG via residue lle1 by making van der Waals contacts with residues V309 and P307 of the Fc [27, 55]. In addition, increasing evidence supports the possibility for Fab regions to modulate the interaction with FcRn [56-59]. The key interactions between hFcRn and human IgG1 (hlgG1) Fc are given in Fig. 2.

The other ligand, albumin $(66.5 \mathrm{kDa})$, is the most prevalent blood protein, with a concentration of $20-40 \mathrm{mg} / \mathrm{mL}$ and $35-50 \mathrm{mg} / \mathrm{mL}$ in mice and humans, respectively [32,60,61]. Its natural function is to transport a range of small insoluble cargos, including fatty acids, hormones, metal ions and waste products, for delivery to tissues and organs [60]. Due to its hydrophobic binding capacity and high aqueous solubility, albumin may be used as a transporter for poorly soluble drugs [62]. Also, it is an attractive fusion partner for protein-based drugs for half-life extension [63]. In contrast to the multi-domain structure of IgG, human serum albumin (HSA) contains a non-glycosylated single polypeptide made up of 585 amino acids, which forms a heart-shaped structure with three homologous domains (denoted DI, DII and DIII) [64]. These are connected via flexible loops, where each domain can be divided into two subdomains ( $A$ and $B$ ) [64]. While DIII contains the principle-binding site for $\mathrm{hFcRn}$, DI modulates the interaction $[34,35,37,65]$. Hydrophobic residues of the subdomains DIIIA and DIIIB make contacts with the hFcRn residues W59 and W53, located within a pH-sensitive $\alpha 1$-domain loop $[35,65,66]$. At acidic $\mathrm{pH}$, the histidine residue at position 166 within the FcRn a2-domain (H166) is protonated and interacts with E54 and Y60 in the $\alpha 1$-domain loop, which stabilizes the orientation of the loop required for efficient albumin binding $[34,35,37,65,66]$. Substitution of $\mathrm{H} 166$ with an alanine abolishes binding to albumin $[33,34,66]$. In addition, other DIII residues, including histidine residues (H464, H510 and H535) and K500, are required for strong binding at acidic pH [34, 35, 65]. Targeting of these residues by mutagenesis reduces receptor binding considerably, which results in short half-lives in hFcRn transgenic mice [34]. The contribution from DI is minor but important for optimal hFcRn binding. Notably, a recombinant form of HSA DIII binds 10 -fold weaker to hFcRn than the full-length version $[67,68]$. Structurally, the DI residues involved are N109, N111 and R81-D89 that make contacts with K63, S58, and T153 of hFcRn, respectively $[35,65,67]$. Close-ups of the interactions between hFcRn and HSA are given in Fig. $\mathbf{2}$. 


\subsection{Recycling and transcytosis of ligands}

hlgG and HSA share a half-life of 3 weeks in humans on average [69-71]. This results from their molecular sizes above the renal clearance threshold and FcRn-mediated rescue from intracellular degradation [32, 72-75]. The astonishing role of FcRn in half-life regulation is evident in patients suffering from the rare human disease hypercatabolic hypoproteinemia, who have remarkably low blood amounts of both ligands due to deficient $\beta 2 \mathrm{~m}$ expression and, consequently, low levels of functional FcRn $[76,77]$. In line with this are data from clinical trials where blocking of the IgG binding site on FcRn using anti-FcRn antibodies rapidly reduced the levels of endogenous IgG by up to $80 \%$ [78-81]. In addition, mice lacking FcRn expression have about 4-fold and 2-fold lower levels of IgG and albumin than normal mice, respectively [32, 73 , 74]. As such, FcRn is a key homeostatic regulator of IgG and albumin by transporting the ligands within and across cells via two cellular pathways, recycling and transcytosis. Both processes are regulated by strict $\mathrm{pH}$-dependent binding-and-release interactions between $\mathrm{FcRn}$ and its ligands $[68,72,75,82-84]$.

Insights into how FcRn mediates cellular recycling have been extensively studied by in vitro cellular transport assays combined with advanced imaging technologies, mainly with a focus on $\operatorname{lgG}[72,75,82,85-91]$. However, recent studies have also revealed knowledge about how FcRn transports IgG and albumin simultaneously $[72,84,92]$. Together, the studies demonstrate that the ligands are taken up via passive fluid-phase pinocytosis at neutral $\mathrm{pH}$, followed by entering of acidified endosomal compartments where FcRn is predominantly located. The mildly acidic $\mathrm{pH}$ (6.0-6.5) herein facilitates protonation of the histidine residues and engagement of the receptor. Bound ligands are then rescued from intracellular lysosomal degradation by sorting of the FcRn-ligand complexes to the cell surface, where exposure to neutral pH triggers ligand release from FcRn into the extracellular space. Proteins that do not bind the receptor are rapidly degraded in lysosomes [72, 82]. Studies in mice have shown that both non-hematopoietic and hematopoietic cells are equally important for FcRn-mediated half-life regulation [83, 93-99].

Furthermore, FcRn can transport the ligands in both directions across polarized cellular barriers, such as the epithelial cell layers of the lungs and the intestine [22, 52, 68, 83, 100-108]. Regarding the polarized intestinal epithelium of the GIT, IgG and albumin are taken up at the basolateral side via fluid-phase pinocytosis, where the $\mathrm{pH}$ is neutral, for subsequent delivery to acidified endosomes in which engagement of FcRn directs the transport across the cells. If the $\mathrm{pH}$ at the apical side is neutral, the ligands will be released. However, where the intestinal lumen milieu is mildly acidic, the ligands may remain bound to the receptor and, again, be taken up by 
the cells, either in a monomeric form, or as IgG-containing immune complexes. This may result in either recycling at the apical side or transcytosis through the polarized epithelial cell layers for release at the basolateral side into lamina propria. The ligands may then be transported via the lymphatic system and enter the systemic circulation via the thoracic lymph nodes, or be processed by immune cells as IgG-containing immune complexes, as recently reviewed $[99,109]$. FcRn-mediated transcytosis has been studied in vitro by the use of Transwell $^{\circledR}$ assays with polarized epithelial cell lines that either endogenously express the receptor or are manipulated to overexpress the receptor $[52,68,83,102-104,106,108]$. In addition, transcytosis across mucosal epithelial barriers has been studied in vivo, either by administering the ligands systemically followed by sampling at mucosal sides $[101,105,107]$, or by giving them via mucosal sites in a needle-free manner followed by sampling of tissues or blood over time [22, $53,68]$. The principles of FcRn-mediated recycling and bidirectional transcytosis are shown in Fig. 3.

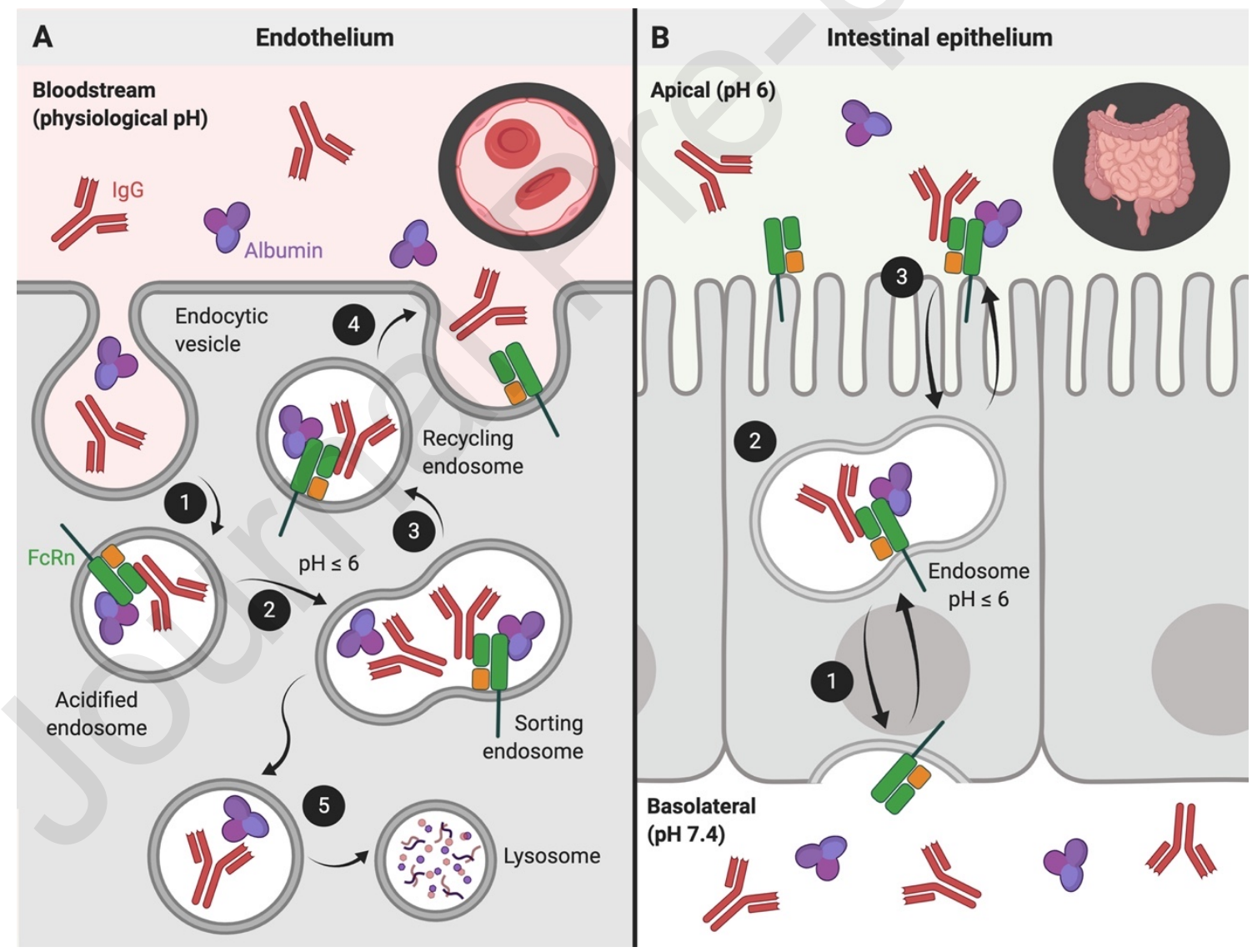

Fig. 3 | Schematic illustration of FcRn-mediated recycling and bidirectional transepithelial transport. (A)

Recycling: (1) IgG and albumin are internalized into cells expressing FcRn, such as vascular endothelial cells, via fluid-phase pinocytosis, and subsequently (2) bind FcRn located within acidic endosomes. (3) The receptor-ligand complex is then recycled back to the cell surface, (4) where the ligands are released into the systemic circulation upon exposure to the neutral pH following exocytosis. (5) Proteins that do not 
bind FcRn are catabolized in lysosomal compartments. (B) Transcytosis: (1) In polarized epithelial cells, such as enterocytes, IgG and albumin are taken up via fluid-phase pinocytosis at the basolateral side where the $\mathrm{pH}$ is neutral. (2) Ligands are subsequently sorted into acidified endosomes where they bind to FcRn. (3) The receptor-ligand complex is then directed to the apical surface of the cells, where it promotes the release of ligands upon exposure to acidic $\mathrm{pH}$ of the intestinal mucosa. In addition, the ligands may remain bound to the receptor and be taken up by the cells again. The figure was created with BioRender.

\section{IgG- and albumin-based drug delivery of antidiabetic peptides}

About $90 \%$ of patients diagnosed with DM have T2DM, while the remaining have type 1 DM (T1DM) [1]. The primary aim of T2DM treatment is to maintain glycemic control by antidiabetic medication. This can be achieved by the use of GLP-1 peptide analogs that stimulate insulin secretion by pancreatic beta cells, or insulin analogs that promote efficient glucose disposal. However, such peptides have a very short half-life of about a few minutes, due to their small size and rapid clearance from the circulatory system via kidney filtration. Hence, efficient treatment would require regular monitoring and frequent dosing schedules [1]. To improve the efficacy and patient compliance of DM therapy, the natural long half-life of hlgG4 Fc and HSA may be used in drug design, which have already been explored for a range of antidiabetic peptides (Table 1).

The first GLP-1 analog to reach the market was liraglutide (Victoza ${ }^{\circledR}$ ), which is linked to a fatty acid (palmitic acid) that binds reversibly to hydrophobic pockets of HSA [110]. As such, it associates non-covalently with endogenous HSA in the subcutaneous tissues and bloodstream. This strategy extends the half-life to 11-15 hours and allows for once-daily dosing [110-112]. Another example is the zinc-based taspoglutide, where aminoisobutyric acid is covalently linked to two positions on GLP-1. This was shown to extend the half-life up to 2-3 days in humans [113, 114]. However, clinical testing was halted due to severe gastrointestinal side effects and hypersensitivity reactions [115]. Furthermore, for the treatment of not only T2DM but also T1DM, other fatty acid-based strategies have been developed for insulin. Examples are insulin detemir $\left(\right.$ Levemir $\left.^{\circledR}\right)[116,117]$ and insulin degludec $\left(\right.$ Tresiba $\left.^{\circledR}\right)[118,119]$. Both are recombinant human insulin analogs with a fatty acid linked to a lysine residue, while insulin degludec also lacks a threonine residue. Insulin detemir and insulin degludec have distinct half-lives of 18-26 hours and 42 hours, respectively [63, 116-120]. An insulin analog with an activity profile close to that of insulin detemir is insulin glargine (Lantus ${ }^{\circledR}$ ) with a half-life of about 24 hours [121]. Instead of modification of the fatty acid side chains, insulin glargine includes two additional arginine residues in the beta chain and an amino acid replacement of asparagine at position 21 with glycine. Nevertheless, these products have gained market approval for once-daily dosing. 
To further extend half-lives of insulin analogs, insulin icodec has been developed as a onceweekly insulin that is currently in phase I and phase III clinical trials in patients with T1DM and T2DM, respectively $[122,123]$. As a result of three amino acid substitutions and the addition of an icosane fatty diacid to this insulin analog, it shows an extended half-life of 8 days in humans and improved stability and solubility.

Despite the fact that these strategies provide prolonged blood persistence compared with native peptides, treatment relies on subcutaneous injections. To allow oral administration, semaglutide has been developed [124]. It is a modified GLP-1 analog where alanine and lysine residues at positions 8 and 34 have been replaced with 2-aminoisobutyric acid and arginine, respectively, to prevent degradation by dipeptidyl peptidase-4 (DPP-4). In addition, lysine at position 26 is engineered to contain a spacer and a fatty acid that can bind endogenous HSA upon injection. This formulation provides a half-life of about 7 days in humans $[125,126]$. When semaglutide is co-formulated with an absorption enhancer, namely sodium N-(8-[2hydroxybenzoyl]amino) caprylate, which neutralizes the $\mathrm{pH}$ of the gastric fluid and hinders enzymatic activity, it is protected from degradation in the GIT following oral administration [124]. The injected version of semaglutide $\left(\mathrm{Ozempic}^{\circledR}\right)$ was clinically approved in the US and Europe in 2017-2018, while the oral formulation (Rybelsus ${ }^{\circledR}$ ) was approved last year [124, 127129]. The latter is the first GLP-1 receptor agonist to be approved for oral administration. Notably, there may be room for further optimization as its oral bioavailability is limited ( $\leq 1.0 \%)$ $[130,131]$.

Currently, there are no oral insulin (OI)-based drugs available for DM treatment. However, very recently, the first clinically tested once-weekly OI analog, named OI338, demonstrated efficacy near subcutaneously injected insulin glargine [132], which has led to the development of longacting Ol formulations [133]. Commonly, a tyrosine at position 14 and a phenylalanine at position 25 are replaced by glycine and histidine, respectively, in addition to a deletion of threonine at position 30 [133]. These amino acid modifications make OI less susceptible to degradation in the GIT upon oral administration $[132,133]$, in combination with the use of an absorption enhancer, such as Gastro Intestinal Permeation Enhancer Tablet I (GIPET ${ }^{\circledR}$ 1) based on sodium caprate [134]. To gain improved HSA binding, the lysine residue at position 29 of the $\mathrm{OI}$ is coupled to a strong albumin binding molecule (C18 fatty diacid) via a hydrophilic linker. Moreover, OI molecules can be designed for prolonged half-life by engineering for decreased insulin receptor affinity. This design resulted in OI338 with a half-life of 70 hours in T2DM patients [132].

In the context of FcRn, it has been demonstrated that binding of fatty acids to the hydrophobic pockets of HSA fact negatively affects receptor binding, in which the effect depends on the 
length of the fatty acid [65]. As such, half-life extension upon conjugation to fatty acids will have limitations. Regarding oral delivery, this means that fatty acid-based strategies may not benefit from albumin binding to FcRn expressed at epithelial cell barriers in the GIT. This is a highly interesting topic that should be addressed in future studies.

An alternative strategy to non-covalent association with HSA is site-specific conjugation. One example is GLP-1 receptor agonist exendin-4 [135-137]. Notably, exendin-4 increases insulin secretion in a glucose-dependent manner at the same time as it stimulates $\beta$-cell proliferation and restores sensitivity to glucose [138]. When injected in the absence of HSA, it has a half-life below 1 hour $[138,139]$. However, when linked to HSA (CJC-1134-PC), it has been shown to gain a half-life of about 8 days in a phase II clinical trial $[111,136,140]$. This allows for once-a-week dosing. Specifically, exendin-4 is linked to HSA via the PC-DAC ${ }^{\text {тM }}$ technology that utilizes maleimide (MAL) chemistry for stable conjugation to the thiol group of a free cysteine residue (C34) in HSA DI $[112,139]$. The same technology has been used for conjugation of insulin (PC$\mathrm{DAC}^{\mathrm{TM}}$ :Insulin), which is under preclinical development and has demonstrated 30 times longer half-life compared with native insulin in rats [141].

Importantly, C34 is distant from the hFcRn interaction site in HSA DI [65, 142]. However, it has been demonstrated that conjugation to C34 may compromise pH-dependent FcRn binding [143145]. How pronounced this effect could be will depend on the biophysical properties of the conjugated drug and, as such, needs to be addressed in a case-to-case scenario. Notably, the loss of receptor binding may be restored by taking advantage of engineered HSA variants containing amino acid substitutions in the C-terminal DIII that improve binding to FcRn, as discussed in Section 5.

Another alternative strategy is to genetically fuse the peptide of interest to the $\mathrm{N}$ - or $\mathrm{C}$-terminal end of HSA. In the context of DM, a di-peptide of GLP-1 has been fused to wild-type (WT) HSA (albiglutide) [146-148], a product known as Tanzeum $^{\circledR}$ in the US and Eperzan ${ }^{\circledR}$ in Europe, which was recently withdrawn from the market due to economic reasons. Nevertheless, the design gave rise to a half-life of 5 days in humans, allowing for weekly subcutaneous injection [146148]. This fusion was based on the addition of the di-peptide to the N-terminal of HSA, which leaves the C-terminal end free. Interestingly, the last leucine residue of the $\mathrm{C}$-terminal end of HSA may be enzymatically cleaved in blood, which has been demonstrated to reduce hFcRn binding and lead to a short half-life in mice and humans [149]. Hence, this biological phenomenon should be considered when designing HSA fusions. A way to compensate for loss of receptor binding is to take advantage of engineered HSA variants with improved receptor affinity, as recently demonstrated [149]. 
The last example is the use of hlgG Fc fusion technology, where a GLP-1 receptor agonist, again engineered to be resistant to enzymatic degradation, is fused to a hlgG4 Fc fragment via a short linker (dulaglutide, Trulicity $^{\circledR}$ ) [150, 151]. IgG4 is likely to be chosen instead of IgG1 due to safety concerns, as IgG4 Fc is less potent in induction of effector functions [43], without altering the ability to engage FcRn. Dulaglutide has a half-life of nearly 5 days in humans, and the product is approved for once-weekly subcutaneous administration [150, 151].

Hitherto, only one of these strategies has been approved for oral delivery. However, in principle, all the antidiabetic peptide strategies may be combined with nanosystems tailored for oral administration to achieve more efficient delivery across the selective mucosal barriers. Although, this will require a sophisticated design that allows the nanosystems to be taken up and delivered to the circulatory system more efficiently than what has been demonstrated to date. This may be achieved by harvesting from recent knowledge about FcRn biology and advances in the engineering of receptor-targeting molecules with favorable binding and transport properties. Such molecules may be directly fused to the peptides, but they may also be used to decorate nanosystems, as discussed in Section 7.

Table 1 | hlgG Fc and HSA as platform for half-life extention of antidiabetic peptides in clinic.

\begin{tabular}{|c|c|c|c|c|c|c|c|c|}
\hline Analog & Name & Ligand & Drug type & Clinical status & $t_{1 / 2}$ & ROA & Company & Reference \\
\hline GLP-1 & Victoza ${ }^{\circledR}$ & HSA & Liraglutide & Marketed & $11-15 \mathrm{~h}$ & SC & Novo Nordisk & {$[110,111]$} \\
\hline \multirow[t]{6}{*}{ (T2DM) } & Rybelsus $^{\circledR}$ & HSA & Semaglutide & Marketed & $6-7 d$ & Oral & Novo Nordisk & {$[124,128,129]$} \\
\hline & Ozempic $^{\circledR}$ & HSA & Semaglutide & Marketed & $7 d$ & SC & Novo Nordisk & {$[127]$} \\
\hline & Trulicity ${ }^{\circledR}$ & hlgG4 & Dulaglutide & Marketed & $4.7-5 d$ & SC & Eli Lilly and Company & {$[150,151]$} \\
\hline & CJC-1134 & HSA & Exendin-4 & Phase II & $8 d$ & SC & ConjuChem & {$[135,136,139]$} \\
\hline & R1538 & HSA & Taspoglutide & Halted phase III & $2-3 d$ & SC & Roche/Ipsen & [113-115] \\
\hline & $\begin{array}{c}\text { Tanzeum }^{\circledR} / \\
\text { Eperzan }^{\circledR}\end{array}$ & HSA & Albiglutide & Withdrawn & $5-8 d$ & SC & GlaxoSmithKline & {$[146-148]$} \\
\hline Insulin & Lantus $^{\circledR}$ & HSA & Insulin glargine & Marketed & $24 \mathrm{~h}$ & SC & Sanofi & {$[121]$} \\
\hline \multirow[t]{5}{*}{ (T1DM, T2DM) } & Levemir $^{\circledR}$ & HSA & Insulin detemir & Marketed & $18-26 \mathrm{~h}$ & SC & Novo Nordisk & {$[116,117]$} \\
\hline & Tresiba $^{\circledR}$ & HSA & Insulin degludec & Marketed & $42 \mathrm{~h}$ & SC & Novo Nordisk & {$[118,119]$} \\
\hline & LAI-287 & HSA & Insulin icodec & Phase I/III & $>8 d$ & SC & Novo Nordisk & {$[122,123]$} \\
\hline & Ol-338 & HSA & Insulin-338 & Phase II & $70 \mathrm{~h}$ & Oral & Novo Nordisk & {$[132,133]$} \\
\hline & PC-DAC ${ }^{\mathrm{TM}}$ & HSA & Insulin & Preclinical & $5-15 h$ & SC & ConjuChem & {$[141]$} \\
\hline
\end{tabular}

$t_{1 / 2}$ : half-life; ROA: route of administration; SC: subcutaneous administration. 


\section{Ligand engineering for improved FcRn binding}

The therapeutic efficacy of many protein-based drug candidates is hampered by their short halflife, and those that have reached the market require frequent administration, which is a burden for the patients. As hIgG and HSA have a naturally long half-life, they are extensively used in therapy, either as full-length hlgG antibodies, or as Fc or HSA fused to therapeutic peptides or proteins of interest $[63,152,153]$.

The in-depth knowledge gained from dissecting of the relationship between FcRn and its ligands at molecular and cellular level has been used in the design of hlgG and HSA variants with improved hFcRn binding and transport properties [38,63, 68, 153-155]. One motivation for this is the high clinical approval rate of monoclonal hlgG antibodies and HSA fusions used to treat a range of different diseases. In fact, hlgG antibodies are the fastest growing class of protein-based drugs, with more than 100 products on the market and impressively over 800 antibodies under clinical testing $[156,157]$. One example is otelixizumab (TRX4), a hlgG1 antibody targeting CD3 to suppress pathogenic T cells, which is used to treat T1DM caused by antigen-specific T cells that infiltrate pancreatic beta cells and lead impaired insulin secretion [158]. While many of the early developed antibodies are based on WT hlgG1, next-generation of monoclonal antibodies will be engineered for either lack or improved effector functions, including optimal hFcRnmediated transport properties [155]. In addition, recent research has also resulted in engineered HSA variants with improved half-life $[65,68,159]$. Moreover, several alternative scaffolds with FcRn-binding properties have been reported [160-164], but a major challenge for such engineering is fine-tuning of strict $\mathrm{pH}$-dependent receptor binding in order to gain favorable recycling and transcytosis capacity. Improvements in FcRn engagement and transport may result in more favorable pharmacokinetic profiles, and consequently less frequent administration and higher patient compliance.

\subsection{IgG Fc-engineering}

Scrutinizing the FcRn-IgG interaction has led to the development of Fc-engineered variants (Fig. 4 and Table 2) where amino acid substitutions within the $\mathrm{CH} 2$ and $\mathrm{CH} 3$ domains have been modified to gain improved $\mathrm{pH}$-dependent binding to hFcRn. Importantly, a prerequisite for successful engineering is to augment receptor binding at acidic $\mathrm{pH}$ while, at the same time, avoiding increase in receptor affinity at neutral $\mathrm{pH}[38,154,165,166]$. The first proof-of-concept was given in 1997 by isolation of mouse IgG1 (mlgG1) Fc fragments by phage display that gave 3.5-fold improved binding towards mouse FcRn ( $\mathrm{mFcRn}$ ), which resulted in about 1.6-fold extended half-life in conventional mice [167]. This was followed by a generation of hlgG Fc- 
engineered variants with increased affinity for hFcRn, which provided a several fold extended half-life in mice, non-human primates and humans.

One example is the YTE triple mutant variant, with three mutations in the $\mathrm{CH} 2$ domains (M252Y/S254T/T256E) (Fig. 4). The variant has10-fold improved binding at pH 6.0, which resulted in about 3.5-fold extended half-life in non-human primates and humans $[154,168,169]$. Another well-studied hlgG1 variant harbors two substitutions of amino acid residues in the $\mathrm{CH} 3$ domains (M428L/N434S: LS variant) (Fig. 4). The LS variant has 11-fold increased binding to $\mathrm{hFcRn}$ at acidic $\mathrm{pH}$ and negligible binding at neutral $\mathrm{pH}$, which gave more than 3-fold extended half-life in hFcRn transgenic mice and non-human primates [170]. Importantly, such engineering has shown to improve therapeutic efficacy in mouse tumor models when combined with antibodies targeting tumor antigens [170]. In addition, extended half-life improves antibodybased prophylaxis, as shown in non-human primates upon viral challenge $[171,172]$. Clinical data on the use of the LS substitutions have revealed that the antibody can reach a half-life of over 100 days compared to 20 days for the WT counterpart [173, 174].

A range of additional hlgG Fc-engineered variants have been reported with increased persistence over the WT antibody when tested in $\mathrm{hFcRn}$ transgenic mice or non-human primates $[165,166,175-182]$, but these do not reach the same half-life values as that of YTE and LS. However, a few recent examples are of interest. In one report, three double $\mathrm{CH} 2$ mutant variants (M252Y/T256D (YD), T256D/T307Q (DQ) and T256D/T307W (DW)) with enhanced pHdependent binding to $\mathrm{hFcRn}$ resulted in similar extended half-lives in $\mathrm{hFcRn}$ expressing mice and non-human primates as that of LS used for benchmarking [183]. Another recent Fc-engineered variant, combining two mutations in the $\mathrm{CH} 2$ domains with one mutation in the $\mathrm{CH} 3$ domains (L309D/Q311H/N434S (DHS)) (Fig. 4) showed a half-life of 2 to 3-fold beyond that of the clinical stage YTE and LS variants in hFcRn expressing mice [89-91, 95]. Intriguingly, it has only 5-fold improved affinity to $\mathrm{hFcRn}$ at acidic $\mathrm{pH}$ and no detectable binding at $\mathrm{pH} 7.4$ [184]. The authors speculate that this may be explained by complete lack of binding at neutral $\mathrm{pH}$, which warrants further studies on how binding throughout the $\mathrm{pH}$ gradient regulates FcRn-mediated transport within and across cells.

These Fc-engineered variants may be used as fusion partners for therapeutic proteins, such as antidiabetic peptides, to achieve extended half-life and improved bioavailability. Preclinical examples are the combination of Fc-containing YTE or LS variants fused to cytotoxic T lymphocyte-associated protein 4, where both Fc fusion products yielded more than 2-fold extended half-life in non-human primates $[185,186]$. In addition, in vitro studies on transcytosis have demonstrated that Fc-engineering can enhance delivery across polarized epithelial cell monolayers, as shown for hlgG1 antibodies containing LS or YTE substitutions that were 
transported almost twice as efficiently across human epithelial cells as the WT counterpart [43]. Interestingly, the capacity to be transported in a hFcRn-dependent manner could be further enhanced when the Fc-engineered antibodies were administered as multivalent immune complexes [52]. As such, FcRn-directed transepithelial transport may be enhanced by Fcengineering for improved $\mathrm{pH}$-dependent receptor binding combined with increased avidity, factors that should inspire the design of nanosystems aiming for enhanced mucosal delivery.
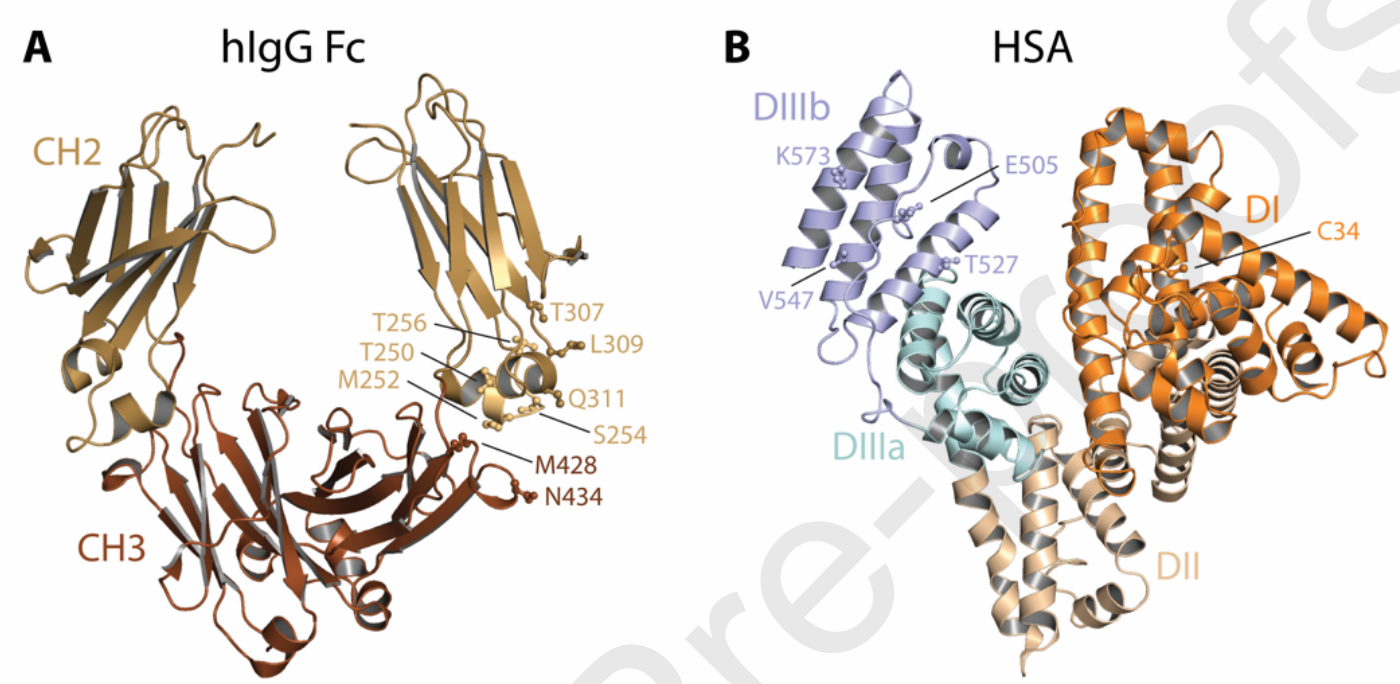

Fig. 4 | Crystallographic illustrations of hlgG and HSA and targeted residues to modify FcRn binding. (A) The $\mathrm{CH} 2$ and $\mathrm{CH} 3$ domains of the hlgG1 Fc are shown in sand and brown, respectively. Residues in the $\mathrm{CH} 2-\mathrm{CH} 3$ elbow region that have been targeted by mutagenesis to increase FcRn binding are indicated. (B) The subdomains DI, DII, DIIla and DIIIb of HSA are colored in orange, wheat, light cyan and light blue, respectively. Residues in the DIIIb subdomain that have been targeted by mutagenesis to increase FcRn binding are indicated. The free cysteine residue, C34, in DI is indicated. The figure was made using PyMol and the crystal structure data deposited of hlgG1 Fc (PDB 1H3W) [187] and HSA (PDB 1BM0) [188].

\subsection{HSA-engineering}

IgG antibodies and Fc fusions have the ability to engage effector molecules, such as the complement factor $\mathrm{C} 1 \mathrm{q}$ and the classical $\mathrm{Fcy}$ receptors, and as such induce a range of effector functions, such as antibody-mediated cellular cytotoxicity or complement dependent cytotoxicity $[43,157]$. Although these immune responses are therapeutically attractive, they may also cause undesirable negative side effects $[157,189]$. To avoid the latter, a solution may be to use the effector-negative HSA as a fusion partner. As the C-terminal DIII of HSA contains the principal binding sites for $\mathrm{hFcRn}[34,35,37,65,190]$, engineering for improved binding has thus far focused on this domain (Fig. 4 and Table 2). Among the first examples to be published 
was a single amino acid substitution introduced in the last $\alpha$-helix (K573P (KP)) (Fig. 4), which gave a 12 -fold stronger binding to $\mathrm{hFcRn}$ at acidic $\mathrm{pH}$ with negligible binding at neutral $\mathrm{pH}$ [159]. This resulted in about 1.5-fold extended half-life in hFcRn transgenic mice and non-human primates compared with WT HSA [159]. Moreover, this albumin variant has been shown to be transported up to 2.5 times more efficient across polarized epithelial cell lines [15, 68]. Similarly, another single amino acid substitution (V547A (VA)) (Fig. 4) showed 13-fold stronger binding to hFcRn at acidic $\mathrm{pH}$, and 1.5-fold longer half-life in hFcRn transgenic mice [65]. However, in an unrelated study, VA gave comparable improved binding to hFcRn to that of KP, but was less well transcytosed across polarized human epithelial cells [68].

Very recently, a triple mutant variant (E505Q/T527M/K573P (QMP)) (Fig. 4) was reported with impressively more than 180 -fold increased hFcRn binding affinity without affecting binding at neutral pH [68]. QMP translated into 4-fold enhanced transcellular transport in vitro, and upon intranasal delivery in $\mathrm{hFcRn}$ trangenic mice, 2-fold more of the engineered variant reached the blood compared with WT HSA. Importantly, following intravenous injection, QMP gained 2-fold longer half-life in vivoin the presence of strong competition with endogenous albumin [68]. The QMP variant has been benchmarked toward a panel of engineered HSA variants and shown to display more favorable binding and transport properties [68]. As such, QMP should be an attractive fusion partner for antidiabetic peptides to achieve prolonged half-life upon subcutaneous or mucosal delivery. The encouraging data on enhanced delivery across polarized lung epithelial barriers should inspire research exploring whether QMP can be used for oral drug delivery to facilitate more efficient uptake and delivery across the selective intestinal epithelium in the GIT.

Table 2 | Examples of engineered hlgG and HSA variants with improved pH-dependent $\mathrm{hFcRn}$ binding. Fold compared with WT hIgG or WT HSA.

\begin{tabular}{|c|c|c|c|c|c|c|}
\hline Ligand & Variant & Mutation & $\begin{array}{l}\text { Increase in hFcRn } \\
\text { binding at pH } 6\end{array}$ & $\begin{array}{l}\text { Increase in } \\
\text { transcytosis }\end{array}$ & $\begin{array}{l}\text { Increase in } \\
\text { half-life }\end{array}$ & Reference \\
\hline \multirow{7}{*}{ IgG } & YTE & M252Y/S254T/T256E & 10-fold & 1.6-fold & $\begin{array}{c}\text { 3.5-fold (humans), } \\
\text { 3.7-fold (NHP) }\end{array}$ & {$[154,168,169]$} \\
\hline & LS & M428L/N434S & 11-fold & 1.9-fold & 3.2-fold (NHP) & {$[170]$} \\
\hline & QL & $\mathrm{T} 250 \mathrm{Q} / \mathrm{M} 428 \mathrm{~L}$ & 29-fold & - & 2.5-fold (NHP) & {$[177]$} \\
\hline & YD & M252Y/T256D & 6.8-fold & - & 1.5-fold (hFcRn Tg mice) & {$[183]$} \\
\hline & $\mathrm{DQ}$ & T256D/T307Q & 7-fold & - & 2.1-fold (hFcRn Tg mice) & {$[183]$} \\
\hline & DW & T256D/T307W & 9.8-fold & - & 1.7-fold (hFcRn Tg mice) & {$[183]$} \\
\hline & DHS & L309D/Q311H/N434S & 5-fold & - & 5.9-fold (hFcRn Tg mice) & {$[184]$} \\
\hline \multirow[b]{2}{*}{ HSA } & VA & V547A & 13.2-fold & - & 1.5-fold (hFcRn Tg mice) & {$[65]$} \\
\hline & KP & K573P & 12-fold & 1.5-fold & $\begin{array}{c}\text { 1.4-fold (hFcRn Tg mice), } \\
\text { 1.6-fold (NHP) }\end{array}$ & {$[68,159]$} \\
\hline
\end{tabular}




\subsection{Alternative engineered FcRn-binding scaffolds}

\subsubsection{FcRn-binding peptides}

Besides engineering of hlgG Fc and HSA, alternative scaffolds with FcRn-binding properties have been developed. One example is the selection of FcRn-binding peptides (FcRnBPs) by phage display technology that bind in the micromolar to nanomolar affinity range at both acidic and neutral pH, and with only minor differences in binding under both conditions (Table 3) [160, 161]. As such, these peptides are not directly attractive for half-life extension. However, a 26amino acid peptide (SYN1436), which blocks the IgG-binding site of FcRn, has been shown to lower the systemic levels of endogenous IgG in mice and non-human primates by up to $80 \%$, but this required the peptide to be dimeric $[160,161]$. Conjugation of polyethylene glycol (PEG) chains to the dimeric peptide affected the binding of FcRn to different degrees [191]. Still, the most optimal PEG-peptide conjugate could accelerate the catabolism of hlgG when administered to hFcRn transgenic mice [191]. Notably, a range of on-going clinical trials are evaluating FcRn-targeting molecules for blockage of the $\lg G$ site, as a strategy to lower the levels of pathogenic IgG in autoimmune diseases, as reviewed [192-194].

Inspired by the work on SYN1436, Sockolosky and colleagues created an engineered version by introducing a single point substitution $(\mathrm{Y} 12 \mathrm{H})$ to make it bind more $\mathrm{pH}$-dependently to the receptor [195]. When fused to the $\mathrm{N}$ - or C-terminal of a model fusion partner, or both, it bound hFcRn without affecting the biological function of the fusion partner. Notably, the fusion proteins harboring an FcRnBP on each end, bound hFcRn with an apparent $K_{d}$ comparable to that of hlgG1 at pH 6.0, but unlike for hIgG1, binding was also detected at pH 7.4. Furthermore, one of the fusion proteins was shown to be transcytosed 14-fold more efficiently than the nonfused counterpart across $\mathrm{hFcRn-expressing} \mathrm{polarized} \mathrm{epithelial} \mathrm{cell} \mathrm{monolayers,} \mathrm{but} \mathrm{not} \mathrm{to} \mathrm{the}$ same extent as that to hlgG1 $[195,196]$. The ability of the fused FcRnBPs to extend the half-life or deliver the fusion partner across mucosal barriers in vivo was not addressed in this study. However, in another study, $\mathrm{Y} 12 \mathrm{H}$-containing FcRnBPs were used to build a panel of antibody Fab fusions with linear and cyclic versions of the peptides that were fused to the light chain or heavy chain of the Fab at either the N- or C-terminal end, or both, via a glycine-serine-linker [196]. The fusion proteins were shown to have varying degrees of receptor binding activity and ability to be transported across polarized human epithelial cells in vitro. In addition, determination of the half-life in non-human primates revealed that a fusion with four linear FcRnBPs fused to the N- 
and C-terminal ends of both light and heavy chains gave the greatest systemic exposure [196]. While the half-life of a Fab fragment was measured to be only about 3-5 hours due to its molecular weight below the renal clearance threshold, the fused FcRnBPs could extend the halflife to 67 hours, which is far from that of IgG and albumin with a half-life of about 5 days in nonhuman primates $[159,168]$. In spite of this, the study pinpoints the importance of avidity for efficient receptor engagement and transport.

\subsubsection{Engineered protein domains}

Protein domains (16kDa) with FcRn-binding properties have been generated by combining the $\mathrm{CH} 2$ domain of an IgG1 Fc (m01s) with the grafting of a stretch of five amino acids derived from the $\mathrm{CH} 3$ domain, containing the key FcRn interaction residues H433 and H435 (Table 3) [163]. Although this fusion bound $\mathrm{hFCRn}$, further engineering was done by the use of phage display to select mutant versions with increased and strict $\mathrm{pH}$-dependent binding to the receptor. One such variant $(2 \mathrm{C} 10)$ showed the capacity to be transcytosed across polarized epithelial cells in a Transwell $^{\circledast}$ system but did not perform as well as the hlgG1 Fc fragment. When tested in nonhuman primates, the half-life was measured to be $40-44$ hours, which was more than 3-fold longer than that of m01s [163]. While this example shows that protein domains with a size below the renal clearance threshold combined with FcRn-binding properties can be rescued from degradation in vivo, the gain in half-life was modest compared with full-length hlgG.

In another phage display approach, single chain variable fragments ( $\mathrm{scFv}$ ) were selected towards hFcRn, which yielded candidates (FnAb-8 and FnAb-12) with nanomolar affinity at acidic $\mathrm{pH}$ (Table 3) [164]. These scFv bound 10 to 100 -fold more strongly to hFcRn than hlgG, and with no or slightly weak binding observed at neutral pH. While FnAb-8 showed overlapping binding with that of IgG, FnAb-12 strengthened IgG binding to the receptor. Further, fusion of FnAb-8 and FnAb-12 to GLP-1 resulted in maintained pH-dependent hFcRn binding as well as binding to the GLP-1 receptor. When FnAb-8 was studied in non-human primates, it revealed a half-life of $100-$ 200 hours, which was about 2-fold longer than that measured for 2C10. Curiously, while the GLP-1 analog exenatide reduced blood glucose concentrations for 2 hours in WT mice, engineered scFvs fused to GLP-1 prolonged this effect for up to 8 hours, despite their inability to engage $\mathrm{mFcRn}[164]$.

The last example is the selection of affibody molecules by phage display selection. This scaffold is a three-helix bundle based on a domain $(6 \mathrm{kDa})$ derived from IgG-binding Protein A from

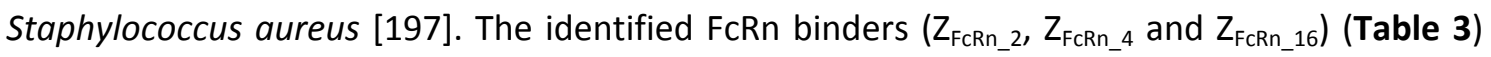
were shown to bind to the receptor in a $\mathrm{pH}$-dependent manner, not only to $\mathrm{hFcRn}$ but also 
mFcRn, where binding was mediated by the presence of two histidine residues that gave 20 to 43-fold stronger binding than that of hlgG [162]. Fusion of the affibody molecules to an albuminbinding domain (ABD), which will hijack albumin in vivo, resulted in a half-life of 91-73 hours, which was 1.6 to 2.7 -fold longer than that of a control protein when injected in mice expressing mFcRn [162]. Notably, ABD interacts with albumin across species without affecting FcRn binding [198]. Lastly, when ABD-fused $Z_{\text {FCRn_z }}$, which bound less pH-dependent, was tested for its ability to out-compete IgG binding to the receptor, a reduction of up to $40 \%$ in IgG levels was measured in mice [199].

Table 3 | Engineered FcRn binding peptides and domains.

\begin{tabular}{|c|c|c|c|c|c|}
\hline Ligand & Name & Sequence $^{a}$ & $\begin{array}{c}K_{\mathrm{d}} \text { at } \mathrm{pH} 6.0 \\
(\mathrm{nM})\end{array}$ & $\begin{array}{c}K_{\mathrm{d}} \text { at } \mathrm{pH} 7.4 \\
(\mathrm{nM})\end{array}$ & Reference \\
\hline \multirow{8}{*}{ FcRnBP } & SYN722 & QRFCTGHFGGLYPCNGP & $5,700^{*}$ & $45,000 *$ & \multirow{8}{*}[160,161]{} \\
\hline & SYN723 & GGGCVTGHFGGIYCNYQ & $5,200 *$ & $35,000 *$ & \\
\hline & SYN724 & KIICSPGHFGGMYCQGK & $22,000 *$ & $78,000 *$ & \\
\hline & SYN725 & PSYCIEGHIDGIYCFNA & $8,800 *$ & $76,000 *$ & \\
\hline & SYN726 & NSFCRGRPGHFGGCYLF & $9,400 *$ & $93,000 *$ & \\
\hline & SYN746 & AC-NH-[QRFCTGHFGGLYPCNGP]-CONH ${ }_{2}$ & $5,100 *$ & $30,000 *$ & \\
\hline & SYN1327 & Ac-NH-[RF-Pen-TGHFG-Sar-NMeLeu-YPC]-CONH${ }_{2}$ & $31 \pm 4^{*}$ & $170 \pm 20 *$ & \\
\hline & SYN1436 & Dimer of -[RF-Pen-TGHFG-Sar-NMeLeu-YPC]-CONH ${ }_{2}$ & $<0.5^{*}$ & $<0.8^{*}$ & \\
\hline \multirow{3}{*}{ Protein domain } & $\mathrm{m} 01 \mathrm{~s}$ & & Low* & Low* & \multirow{3}{*}[163]{} \\
\hline & $a 2 b$ & (m01s)-RCPRWMRTPHNHYT & $2,200^{*}$ & Negligible* & \\
\hline & $2 \mathrm{C} 10$ & (m01s)-FGNCAYLRPHNHYT & $1,100 *$ & Low* & \\
\hline \multirow{2}{*}{ SCFv } & FnAb-8 & - & $4.32 *$ & Negligible* & \multirow[t]{2}{*}[164]{} \\
\hline & FnAb-12 & - & $43.2^{*}$ & Low* & \\
\hline \multirow{3}{*}{ Affibody } & $Z_{\mathrm{FcRn} \_2}$ & $\begin{array}{l}\text { VDAKYAKEQDAAAHEIRWLPNLTFDQRVAFIHKLADDPS } \\
\text { QSSELLSEAKKLNDSQAPK }\end{array}$ & $12^{\#}$ & $>500^{\#}$ & \multirow{3}{*}{ [162] } \\
\hline & $\mathrm{Z}_{\mathrm{FcRn}}$ & $\begin{array}{l}\text { VDAKYAKEFESAAHEIRWLPNLTYDQRVAFIHKLSDDPSQ } \\
\text { SSELLSEAKKLNDSQAPK }\end{array}$ & $50^{\#}$ & $>1,000^{\#}$ & \\
\hline & $Z_{\text {FcRn_16 }}$ & $\begin{array}{l}\text { VDAKYAKEWMRAAHEIRWLPNLTFDQRVAFIHKLEDDPS } \\
\text { QSSELLSEAKKLNDSQAPK }\end{array}$ & $14^{\#}$ & $>500^{\#}$ & \\
\hline
\end{tabular}

(a) Single-letter amino acid codes are used except for Pen, I-penicillamine; NMeLeu, I-N-methylleucine; Sar, sarcosine. Amino acids colored in orange are connected by a disulfide bridge. Binding affinity $\left(K_{\mathrm{d}}\right)$ was determined by $(*)$ surface plasmon resonance and $(\#)$ biosensor analysis.

\section{The importance of considering cross-species FcRn differences for preclinical evaluation}

Non-human primates are considered the most suitable animal model for preclinical testing of hlgG- and HSA-based drugs, but economic and ethical reasons exclude them from routine screening of drug candidates and exploration of proof-of-concepts [200]. On the other hand, 
mouse models are more suitable for initial preclinical assessment due to their convenience, costeffectiveness and genetic background. However, the examples given in this review on engineered hIgG Fc and HSA variants with improved FcRn binding properties, which will be presented in Section 5, were all evaluated in mice transgenic for hFcRn prior to testing in nonhuman primates. The reason for this is that there are large cross-species ligand binding differences between the mouse and human forms of FcRn that must be taken into consideration to obtain reliable preclinical in vivo data.

\subsection{Biology of FcRn and its ligand in mice and humans}

FcRn is expressed in almost all cell types and tissues of the body, with a few exceptions, as described [201, 202]. Regarding its role in transcytosis of IgG, FcRn has been shown to mediate the delivery of endogenous IgG from the mother to the fetus via transplacental transport during the third trimester of pregnancy $[203,204]$. This secures passive immunity of the newborn at a critical time of life. In mice, such transport occurs via the placenta, but primarily via intestinal uptake of neonatal mice during the suckling period, when large amounts of IgG are taken up from the mother's milk via pH-dependent FcRn-directed transcytosis [205]. Interestingly, while the intestinal tissue expression of FcRn in humans is maintained throughout life, it is developmentally downregulated in conventional mice $[93,206]$. For this reason, caution should be taken when addressing FcRn-targeting approaches and it has been suggested that such studies should be performed no later than 6-16 weeks after weaning in mice expressing $\mathrm{mFcRn}$ [207]. Notably, $\mathrm{mFcRn}$ is expressed at high levels in the duodenum and jejunum during neonatal life $[206,208,209]$. In humans, hFcRn is expressed in different sections of the human intestine, including the colon and ileum, but somewhat less in the jejunum and duodenum $[108,201,207$, 210]. Although the FcRn expression of intestinal tissues is down-regulated in mice, it persists in other tissues throughout life and, as such, regulates half-life and biodistribution of IgG and albumin.

Despite the fact that the mouse and human forms of the FcRn heavy chain share nearly $70 \%$ similarity in the amino acid composition, and that the key interacting residues responsible for $\mathrm{pH}$-dependent binding are conserved $[26,211]$, there are distinct variations that result in large differences in cross-species binding. Specifically, this results in no or very poor binding of $\mathrm{mlgG}$ to the human receptor, while hlgG binds more strongly to the mouse receptor than to the human form [212, 213]. As such, hlgG Fc-engineering for improved binding to hFcRn does not translate into extended half-life in conventional mice, but rather shorter half-life than the WT counterpart, as engineering for more favorable $\mathrm{pH}$-dependent binding is not preserved [72, 
214]. This is the case for all hlgG Fc-engineered variants reported to date, which means that they cannot be used in mouse models expressing mFcRn.

In contrast to hlgG, HSA binds very poorly to $\mathrm{mFcRn}$, with more than 20 -fold weaker binding than mouse serum albumin (MSA), whereas MSA binds slightly stronger than HSA to hFcRn [34, $200,212,215,216]$. Thus, HSA injected into conventional mice is out-competed for binding to $\mathrm{mFcRn}$ in the presence of high amounts of natural endogenous MSA, produced continuously by the liver. This means that HSA is not rescued from intracellular degradation in mice expressing mFcRn, as illustrated by the fact that WT HSA has a nearly identical half-life as HSA engineered for considerably reduced binding to hFcRn [159]. Therefore, studies conducted under such conditions do not take into consideration the contribution of FcRn and, as such, this preclinical setting is non-physiological. The molecular explanations for the large cross-species differences have been described in depth elsewhere $[75,159,200,215,217,218]$.

\subsection{Human FcRn transgenic mouse models}

To solve this preclinical challenge, several genetically engineered mouse strains have been developed where the $\mathrm{mFcRn}$ heavy chain has been replaced with the human counterpart, either under the control of mouse or human promoter elements [32, 74, 181, 216, 219-223]. These strains are the current gold standards for the evaluation of hFcRn-targeting strategies addressing pharmacokinetics, pharmacodynamics and delivery across selective mucosal barriers prior to studies in non-human primates.

The most commonly used $\mathrm{hFCRn}$-expressing strains are generated from conventional C57BL/6J mice, named Tg32 and Tg276 (Fig. 5A), which are extensively used to assess the half-life of hlgG and HSA $[32,74,181,220,222,223]$. Both strains have substituted the mouse heavy chain with that of the human form, which can pair non-covalently with the endogenous mouse $\beta 2 \mathrm{~m}[32$, $74,181,222,223]$. A distinct difference between these strains is that the $\operatorname{Tg} 32$ mice express the heavy chain under the control of its human regulatory elements [74, 181, 220, 222, 223], while the expression in Tg276 mice is regulated by a constitutive CAG promoter, a human cytomegalovirus enhancer fused to chicken $\beta$-actin/rabbit $\beta$-globin hybrid $[32,181]$. This results in a much more widespread expression profile of $\mathrm{hFcRn}$ in $\mathrm{Tg} 276$, whereas the receptor expression profile in $\operatorname{Tg} 32$ mice has been mapped to be similar to that in humans [201, 224]. There is also a modified version of Tg32 that expresses human $\beta 2 \mathrm{~m}$, but no difference in halflife of the ligands has been reported that can be related to whether the mice carry a mouse or human form of $\beta 2 \mathrm{~m}$ [222]. In general, the half-life of hlgG is shorter in Tg276 homozygous mice relative to the $\operatorname{Tg} 32$ strain, and longer in the Tg32 hemizygous than the homozygous strain [222]. Since the expression profile of the Tg32 strains resembles more closely to that of humans, 
studies of FcRn in mucosal immunity and receptor targeting for delivery across the epithelial barriers have been mainly studied in these mice, as recently reviewed [99]. Therefore, the Tg32 strains should be used for studies addressing the mucosal delivery of FcRn-targeted molecules or nanosystems.

In humans, injected hIgG and HSA will compete for binding to FcRn in the presence of high concentrations of IgG $(10 \mathrm{mg} / \mathrm{mL})$ and albumin $(40 \mathrm{mg} / \mathrm{mL})$, produced by the plasma cells and liver, respectively. This is in stark contrast to what has been found in mice kept under pathogenfree housing, where the concentrations of endogenous mlgG are low (roughly 1.0-0.2 mg/mL) compared to those found in nature, while the concentrations of MSA are high $(20-50 \mathrm{mg} / \mathrm{mL})$ due to constitutive production by the liver $[32,225]$. These conditions must be taken into consideration in the preclinical evaluation of FcRn-targeted strategies, since the outcome can be greatly affected by a lack of competition for receptor binding, as in the case of the IgG binding site, which is in contrast to strong competition for the albumin-binding site. To address how competition for the IgG binding site of FcRn affects targeting approaches, mice may be preloaded with excess amounts of hlgG prior to administration, which has been shown to modulate the half-life of injected IgG variants $[181,219,226]$. Interestingly, a modified version of the Tg32 strain has been recently reported to produce hlgG1 Fc combined with mlgG Fab arms, which is rescued by hFcRn (Fig. 5B) [219]. The levels of endogenous chimeric mouse-human IgG1 were shown to be greatly increased upon immunization, which modulated the half-life of injected hlgG. Thus, this Tg32-hFc mouse model may be attractive for studies addressing competition for the IgG binding sites. A similar mouse model that also expresses the human classical Fcy receptors has been reported [227].

Regarding studies of HSA-based strategies, a version of Tg32 that lacks expression of MSA has been developed [221]. This model allows for studies in the absence of competition, but also in the presence of HSA following preloading (Fig. 5C). An alternative to this is a mouse strain, named Albumus ${ }^{\mathrm{TM}}$, that has been genetically modified to express both $\mathrm{hFcRn}$ and HSA (Fig. 5D) [216]. However, the expression of the heavy chain of hFcRn is not under the control of the human promoter. Despite this, studies of engineered HSA variants in Tg32 with competition and in the double transgenic mouse model have revealed similar half-lives [159, 216, 223]. Due to differences in the construction of these strains, they may differ in their expression of the receptor in different mucosal tissues, which has not yet been studied in detail. Importantly, it has recently been shown that competition for the albumin-binding site strongly affects the halflife of injected HSA $[68,221]$. While the half-life in Tg32 mice lacking expression of albumin was measured to be around 3 weeks for injected WT HSA, it was only a few days in the presence of competition $[68,221]$. This demonstrates that the competitive pressure is high for the albumin- 
binding site of FcRn. As such, only minor alterations in the binding kinetics of WT HSA fusions may affect their half-life. To compensate for this, HSA engineered for improved hFcRn binding may be used. When an engineered albunin, called QMP HSA, was compared with WT HSA in Tg32 mice lacking albumin, it only showed a 1.2-fold longer half-life, whereas a 2-fold difference was measured in the presence of competition [68]. The same effect of competition was observed when the HSA variants were administered intranasally, followed by homing to the lungs and uptake into the bloodstream [68]. Moreover, when QMP was fused to an antibody fragment, more than 4-fold the amount of WT fusion was detected in the blood for 24 hours following intranasal administration, which corresponded to around $10 \%$ of the dose given [68]. Importantly, uptake and transport across the mucosal lung barriers were much more efficient for HSA than for hIgG [68]. As such, QMP should be an attractive fusion partner for more favorable pharmacokinetics and transepithelial delivery, as previously discussed.
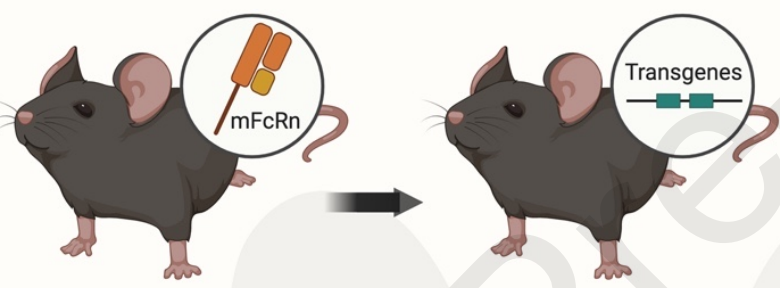

Conventional C57BL/6J

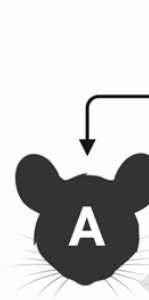

Tg32 and Tg276

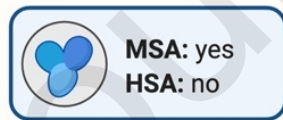

mIgG: low chlgG1: no
Human FcRn transgenic mouse models

\section{mFcRn: no} hFcRn: yes

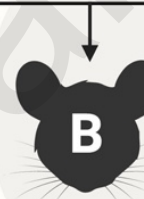

Tg32-hFc

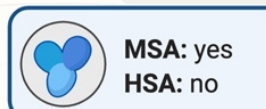

HSA: no

mlgG: low chlgG1: yes

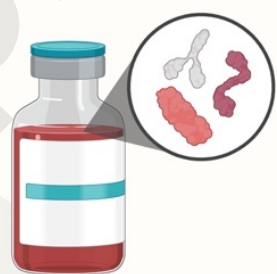

Preclinical evaluation

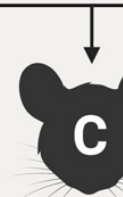

Albumin knockout

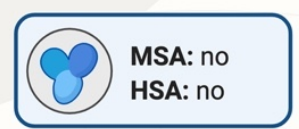

mlgG: low chlgG1: no

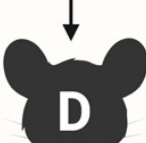

Double transgenic

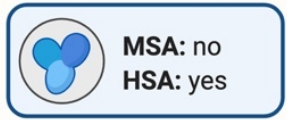

migG: low chlgG1: no

Fig. 5 | hFcRn transgenic mouse models for evaluation of hlgG and HSA-based therapeutics.

Conventional $\mathrm{C} 57 \mathrm{BL} / 6 \mathrm{~J}$ mice have been used to generate humanized mouse strains that are transgenic for $\mathrm{hFcRn}$. While (A) the Tg32 and Tg276 strains express mlgG, (B) the Tg32-hFc strain expresses chimeric hlgG1 (chlgG1). In comparison to these mouse strains, (C) Tg32 albumin knockout mice do not express MSA, while (D) the double transgenic mouse model (Albumus ${ }^{\mathrm{TM}}$ ) has both $\mathrm{hFcRn}$ and HSA. The figure was created with BioRender. 


\section{FcRn-targeted nanosystems for oral delivery of antidiabetic peptides}

An attractive strategy for enhancing oral delivery of antidiabetic peptides is to encapsulate drugs into NPs [7, 228-230]. Such nanosystems can provide protection against harsh conditions in the GIT, which may enhance uptake and transport across the selective cellular barriers [8,9]. While several reports have shown promising results, oral delivery of NPs is still limited by low bioavailability. Thus, there is a need to make a quantum leap in the design of drug-encapsulated nanosystems to make oral delivery far more efficient. One way to achieve this may be to combine the biotechnological advances of NP design with strategies to target FcRn at mucosal surfaces [11-15]. This may allow active transport across the polarized intestinal epithelium for delivery to the systemic circulation $[11,12,15]$. The NP design must then be done in a way that favors FcRn engagement and transcellular transport, parameters that are not yet fully defined. However, while NPs can be decorated with FcRn-targeting molecules, the encapsulated peptides may also be engineered for efficient FcRn-mediated recycling, as discussed in Section 3, which can improve half-life and bioavailability upon release from the NPs. Herein, a brief overview of parameters that are relevant to be considered in the context of NP design and FcRn-targeting and examples of FcRn-targeted nanosystems encapsulating antidiabetic peptides will be discussed.

\subsection{Design of targeting nanosystems}

The stability and characteristics of nanosystems, including their size, charge, shape, material and coating are parameters that dictate their internalization and transport properties (Fig. 6), as extensively reviewed $[7,8,231-234]$. However, for the NPs to be targeted to FcRn, they must be engineered to display receptor-targeting molecules on their surface in such a manner that will allow for efficient binding-and-release and stability throughout the endosomal $\mathrm{pH}$ gradient. Relevant parameters to be considered are how the $\mathrm{pH}$-dependent binding kinetics of the FcRnbinding molecules affect the ability of the NPs to be transported, and in this context, how the number and density of the targeting molecules and, as such, avidity and flexibility are affecting the outcome [235].

Decoration of NPs with FcRn-targeting molecules could be achieved in a non-covalent manner by adsorption, but preferably covalently to secure stability [236]. To ensure the latter, conjugation should be irreversible and site-specific to fix the orientation of the ligands in such a way that guarantees availability and functional display. One strategy is to use MAL-thiol or carbodiimide chemistry for site-specific conjugation. Regarding the MAL-thiol reaction, it requires coupling of sulfhydryl reactive MAL on the surface of NPs to thiol groups present on 
hlgG or HSA, which will result in irreversible thioether bonds [237]. As hlgG or its Fc fragment does not contain any free cysteine residues, functional groups using primary amine reactive reagents or crosslinkers must be used [11,12]. However, when it comes to HSA, C34 in DI is an attractive site for conjugation [15]. On the other hand, carbodiimide crosslinking can be achieved using 1-ethyl-3-(3-dimethylaminopropyl)-carbodiimide/N-hydroxysuccinimide (EDC/NHS) reaction to form an amide bond between the carboxylic groups of hlgG Fc or HSA and the functionalized aminated NPs $[13,14,238,239]$.

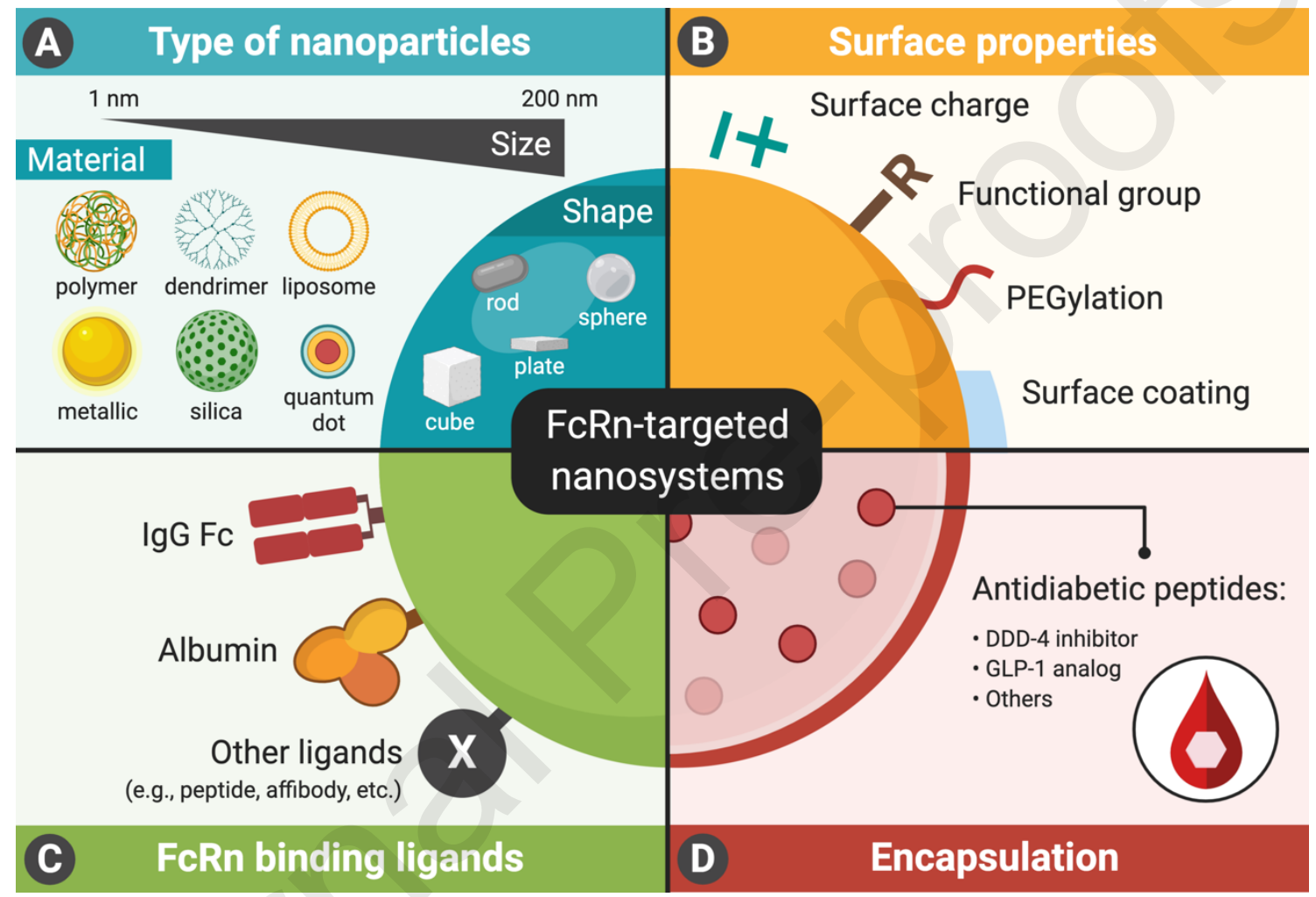

Fig. 6 | Design of FcRn-targeted nanosystems for oral delivery of antidiabetic peptides. The physicochemical characteristics of engineered NPs can be tailored by altering (A) the particle size, shape and composition as well as (B) their surface properties. To ensure efficient transport of the NPs across selective polarized epithelial barriers that express FcRn, the surface of NPs may be decorated with (C) receptor-binding molecules engineered for improved binding and transport properties, such as IgG Fc and albumin. Such nanosystems may be used in the treatment of DM and prevention of fibrosis by (D) encapsulating antidiabetic peptides or fusion proteins, in the internal core of the NPs, allowing for drug protection and controlled release upon oral administration. The figure was created with BioRender.

\section{2. hlgG Fc-decorated nanosystems}

The first FcRn-targeted nanosystems were developed using the Fc fragment of hlgG antibodies as a targeting moiety [11-13]. Several of these studies focused on the use of polymeric NPs as a 
scaffold for drug encapsulation [11, 12, 240]. A major advantage of such polymeric NPs is their biocompatibility and biodegradability, which are desirable features to avoid potential toxicity of a range of inorganic classes of NPs when considering translation of developed nanosystems into a clinical setting $[233,234]$. An example of this is polymer-based nanosystems of poly(lactic acid) (PLA), in which thiolated hIgG Fc was covalently conjugated to the MAL-functionalized NPs, with an average hydrodynamic diameter of about $55 \mathrm{~nm}$, via MAL-thiol reaction [11]. The conjugation of Fc resulted in a slight increase in the particle size and showed a maintained monodispersity of the NPs before and after coupling. Since IgG antibodies generally carry a weakly negative charge under physiological conditions [241], the surface charge of the Fc-decorated NPs (Fc-NPs) became slightly more negatively charged when coupled to the Fc fragments. Interestingly, FcNPs gave a 2-fold rise in transcytosis in vitro compared with non-targeted NPs across a polarized epithelial cell line that endogenously expressed $\mathrm{hFcRn}$, while transport was reduced in the presence of free hlgG Fc competing for receptor binding, suggesting that the increase in uptake and transcytosis was FcRn-dependent [11]. In conventional WT BALB/c mice, which express $\mathrm{mFcRn}$ throughout the small intestine and colon, Fc-targeting of FcRn enhanced in vivo biodistribution of the NPs in several organs, as well as increasing the absorption efficiency by 11.5-fold following oral administration. Importantly, insulin-loaded Fc-NPs showed prolonged hypoglycemic responses in fasted mice when administered orally at a clinically relevant insulin dose compared with non-targeted NPs and to injected insulin, while free Ol solution did not generate a glucose response. This effect was not observed in mice lacking FcRn expression, which may indicate FcRn-induced transcytosis of Fc-NPs in the GIT and, as such, the release of insulin from the NP matrix into blood circulation. While these studies were done in WT mice, further studies on ligands engineered for improved hFcRn binding and transport properties should be performed in mice transgenic for the human receptor $[220,223]$.

A similar strategy has been explored to improve oral efficacy of exenatide, a GLP-1 receptor agonist for T2DM treatment, in which the peptides were loaded into poly(lactic-co-glycolic acid) (PLGA) NPs using the same coupling chemistry as PLA-based nanosystems [12]. The particle size of native PLGA NPs was about $109 \mathrm{~nm}$, which was larger than that of the PLA NPs [11]. The difference in hydrodynamic diameters observed can be explained by the methods used to synthesize NPs and the chemical composition of NP formulations. Similar increase in particle size and surface charge of hlgG Fc-decorated PLGA NPs as that of PLA NPs was observed. In this study, relative to non-targeted nanosystems, Fc-NPs showed to be more efficiently taken up and transcytosed across polarized epithelial cells expressing endogenous hFcRn [12]. Notably, it would be of importance to compare to what degree the particle size may affect the internalization of NPs $[242,243]$. A mouse model of human TD2M ( $d b / d b)$ was used to study the 
hypoglycemic response of the peptide-loaded NPs. Upon oral administration, the Fc-NPs showed a higher reduction in blood glucose levels and particle retention in the GIT compared with nondecorated NPs [12]. Furthermore, FcRn-targeting of Fc-decorated nanosystems exhibited a prolonged hypoglycemic response relative to injected exenatide, although the reduction effect of the injection solution was shown to be more efficient in the first few hours following subcutaneous injection.

In addition to polymer-based NPs, nanosystems may be designed with inorganic components having unique electrical, magnetic and optical properties $[233,234]$. Such inorganic NPs allow for fine-tuning of the size, structure and geometry for enhanced performance that may benefit oral delivery across epithelial barriers of the tailored-made nanosystems. Nevertheless, due to the toxicity and solubility limitations of such NPs, the use of inorganic materials in humans must be carefully examined [244, 245]. An example of inorganic nanosystems explored for oral delivery of antidiabetic peptides is undecylenic acid-coated silicon NPs (SiNPs) that were loaded with GLP-1 [13]. In contrast to the examples of polymeric NP formulations given [11, 12], SiNPs were functionalized with amine-modified Fc via EDC/NHS reaction. The NPs were then treated with mucoadhesive chitosan and eventually entrapped into a $\mathrm{pH}$-responsive polymeric matrix of hypromellose acetate succinate (HPMC) to improve drug adsorption at mucosal sites and prevent premature release of encapsulated drugs under strong acidic conditions in the GIT [13]. The Fc-NPs showed enhanced transcytosis in vitro in polarized epithelial cell lines expressing hFcRn compared with non-targeted NPs, which resulted in higher amounts of GLP-1 released from the NP matrix at the basolateral side of Transwell $^{\circledR}$ system [13].

Overall, these findings have demonstrated that decoration with hIgG Fc fragments may enable the oral delivery of peptide-loaded NPs across epithelial barriers for delivery to the systemic circulation [11-13]. However, in addition to the lack of use of hFcRn trangenic mouse models, $\mathrm{pH}$-dependent binding affinity and functional avidity for the receptor of the Fc ligands decorating the surface of NPs have yet to be examined to ensure optimal receptor-mediated binding and transepithelial transport of nanosystems. Furthermore, the mechanisms of action of the FcRn-targeted NPs should be studied in detail.

\subsection{HSA-decorated nanosystems}

Although hlgG Fc have been explored as FcRn-targeting moieties, their use is impeded due to the need for chemical modification for conjugation. As such, HSA may be used for decoration of NPs owing to low immunogenicity and ease of production [246, 247]. Furthermore, it was very recently shown that HSA was transported more efficiently than hlgG across mucosal lung barriers in vivo in hFcRn transgenic mice [68]. On this basis, HSA may be an attractive targeting 
molecule for favorable FcRn-mediated transepithelial delivery of nanosystems for oral administration of antidiabetic peptides [14, 15, 240].

An example of nanosystems that has been combined with albumin is polymeric alginate-dextran sulfate-based (ADS) NPs with an average hydrodynamic diameter of $233 \mathrm{~nm}$, that were coated with chitosan [240]. In contrast to synthetic PLA and PLGA, the polymers alginate, dextran and chitosan used to synthesize NPs are natural product-derived compounds that provide nanosystems with mucoadhesive characteristics [247]. In this study, bovine serum albumin (BSA) was non-specifically adsorbed onto the surface of ADS NPs [240], in contrary to sitedirected chemical coupling of Fc-decorated NPs [11-13]. In an in vitro model of polarized epithelial cells expressing hFcRn combined with mucus-producing goblet cells, BSA-decorated NPs loaded with insulin showed an improved permeability profile of the peptides compared to free insulin [240]. However, cautious should be taken when interpreting the result since the binding kinetics of BSA for hFcRn is not identical to that of HSA [32]. Aside from that, strategies for surface modification of NPs and pH-dependent functionality of ligands are two other important parameters to address.

An attempt was made to decorate the surface of HPMC-treated undecylenic acid-coated SiNPS with HSA via EDC/NHS reaction [14]. The chemical surface modification of NPs with HSA showed an increase in particle size after conjugation, while maintaining high monodispersity. Interestingly, HSA-conjugated NPs (HSA-NPs) exhibited improved cytocompatibility in human epithelial cell lines relative to non-conjugated NPs, which suggests that decorating nanosystems with biocompatible compounds, such as HSA, may reduce the toxicity of inorganic nanomaterials. Furthermore, the presence of HSA on the NP surface demonstrated enhanced cellular uptake and internalization of nanosystems in vitro with the aid of hFcRn expressed on the cell surface [14]. Done in this fashion, HSA-NPs encapsulating insulin showed enhanced transport of loaded peptides across polarized epithelial cell monolayers in in vitro transcytosis assays. The data also suggested an improvement in the transepithelial delivery of encapsulated antidiabetic peptides when comparing HSA-NPs with IgG Fc-NPs [13], which encourages research on the use of engineered HSA variants tailored for improved hFcRn binding and transport properties as targeting ligands, as discussed in Section 5 [68].

Recently, the KP variant of HSA, which shows a 12-fold improved hFcRn binding compared to WT HSA [159], has been explored in an NP formulation of polymeric PLGA with an average hydrodynamic diameter of about $150 \mathrm{~nm}$ [15]. In this study, the surface of PLGA NPs was functionalized with HSA through MAL-thiol conjugation chemistry, in which no or slight increase in particle size was observed as a result of protein coupling. Most importantly, the $\mathrm{pH}-$ dependent binding characteristics for hFcRn of HSA-NPs were in line with reported studies for 
native HSA $[68,159]$. Compared to WT-decorated NPs, KP-decorated NPs showed enhanced binding to hFcRn at mildly acidic $\mathrm{pH}$ (5.5), while receptor binding was not observed for NPs decorated with an engineered HSA variant that does not bind hFcRn [15]. Similar results were demonstrated in in vitro transcytosis assays, where KP-decorated NPs were transported 2-fold more efficiently than WT-decorated NPs across polarized epithelial cells expressing hFcRn [15]. Intriguingly, when studying the effect of HSA functionalization on the hypoglycemic response of insulin-loaded PLGA NPs in T1DM-induced mice transgenic for hFcRn, KP-decorated NPs showed the most efficient glycemic reduction following oral administration compared with other HSANPs and to Ol solution.

Altogether, engineered HSA shows promise in the next-generation design of FcRn-targeted nanosystems for oral delivery of antidiabetic peptides. The ultimate aim now will be to tailordesign such strategies for further improvement in receptor engangement and transport properties to favor efficient transepithelial transport of NPs across the GIT upon oral administration. The QMP HSA variant should be an attractive FcRn targeting partner for decoration of NPs to achieve not only enhanced mucosal delivery but also prolonged half-life of fused peptides [68].

\section{Conclusions}

Nanosystems as drug carriers have the potential to make a significant impact on the treatment of many diseases, including diabetes and fibrosis. While a number of NP-based strategies have entered clinical trials or have been approved for use, they can only be administered by parenteral delivery methods. An alternative and preferrable approach would be oral administration due to patient convenience and compliance, but this remains a challenge because uptake and delivery across selective intestinal epithelial barriers are limited. Furthermore, frequent administration is often required. As such, design of nanosystems tailored for oral drug delivery is extensively explored to increase the bioavailability of encapsulated drugs. This review highlights how in-depth insights into the biology of FcRn may be used to engineer NPs decorated with receptor-binding molecules with the aim to overcome the highly inefficient uptake at the intestinal epithelial barriers. If this major challenge is solved, it will allow for more cost-effective self-administered methods. In addition, the encapsulated drugs, such as antidiabetic peptides, may also be engineered for extended half-life and increased bioavailability by taking advantage of $\mathrm{pH}$-dependent FcRn engagement. For preclinical testing of such strategies, considerable cross-species FcRn binding differences must be taken into account to secure reliable results from mouse model systems. 


\section{Conflict of interest}

The authors declare no conflict of interest.

\section{Acknowledgements}

This paper was financed by Portuguese funds through FCT - Fundação para a Ciência e a Tecnologia/Ministério da Ciência, Tecnologia e Ensino Superior in the framework of the project "Institute for Research and Innovation in Health Sciences" UID/BIM/04293/2019. Cláudia Azevedo (SFRH/BD/117598/2016) and Soraia Pinto (SFRH/BD/144719/2019) would like to thank to Fundação para a Ciência e a Tecnologia (FCT), Portugal for financial support. S.B., J.N. and J.T.A. were supported by the Research Council of Norway (Grant no. 274993; 287927), and J.T.A. by the South-Eastern Norway Regional Health Authority (Grant no. 2018052; 2019084). 


\section{References}

[1] Y. Zheng, S.H. Ley, F.B. Hu, Global aetiology and epidemiology of type 2 diabetes mellitus and its complications, Nat Rev Endocrinol. 14 (2018) 88-98.

[2] WHO, Classification of diabetes mellitus 2019, Available online on: file://C:/Users/Utilizador/Downloads/9789241515702-eng\%20(1).pdf [accessed on $9^{\text {th }}$ september 2020].

[3] R. Basson, A. Bayat, Chapter 7 - Fibrosis and diabetes: Chronic hyperglycemia triggers organspecific fibrotic mechanisms, in: D. Bagchi, A. Das, S. Roy (Eds.) Wound Healing, Tissue Repair, and Regeneration in Diabetes, Academic Press, 2020, pp. 121-147.

[4] M.J. Fowler, Microvascular and macrovascular complications of diabetes, Clin Diabetes. 26 (2008) 77-82.

[5] C.R. Ban, S.M. Twigg, Fibrosis in diabetes complications: pathogenic mechanisms and circulating and urinary markers, Vasc Health Risk Manag. 4 (2008) 575-596.

[6] A. Sosnik, J. das Neves, B. Sarmento, Mucoadhesive polymers in the design of nano-drug delivery systems for administration by non-parenteral routes: A review, Prog Polym Sci. 39 (2014) 2030-2075.

[7] L.N. Thwala, V. Préat, N.S. Csaba, Emerging delivery platforms for mucosal administration of biopharmaceuticals: a critical update on nasal, pulmonary and oral routes, Exp Opin Drug Deliv. 14 (2017) 23-36.

[8] F. Araújo, J. das Neves, J.P. Martins, P.L. Granja, H.A. Santos, B. Sarmento, Functionalized materials for multistage platforms in the oral delivery of biopharmaceuticals, Prog Mat Sci. 89 (2017) 306-344.

[9] M. Goldberg, I. Gomez-Orellana, Challenges for the oral delivery of macromolecules, Nat Rev Drug Discov. 2 (2003) 289-295.

[10] J.K. Patra, G. Das, L.F. Fraceto, E.V.R. Campos, M.D.P. Rodriguez-Torres, L.S. Acosta-Torres, L.A. Diaz-Torres, R. Grillo, M.K. Swamy, S. Sharma, S. Habtemariam, H.S. Shin, Nano based drug delivery systems: recent developments and future prospects, J Nanobiotechnol. 16 (2018) 71.

[11] E.M. Pridgen, F. Alexis, T.T. Kuo, E. Levy-Nissenbaum, R. Karnik, R.S. Blumberg, R. Langer, O.C. Farokhzad, Transepithelial transport of Fc-targeted nanoparticles by the neonatal Fc receptor for oral delivery, Sci Transl Med. 5 (2013) 213 ra167.

[12] Y. Shi, X. Sun, L. Zhang, K. Sun, K. Li, Y. Li, Q. Zhang, Fc-modified exenatide-loaded nanoparticles for oral delivery to improve hypoglycemic effects in mice, Sci Rep, 8 (2018) 726.

[13] J.P. Martins, D. Liu, F. Fontana, M.P.A. Ferreira, A. Correia, S. Valentino, M. Kemell, K. Moslova, E. Mäkilä, J. Salonen, J. Hirvonen, B. Sarmento, H.A. Santos, Microfluidic nanoassembly of bioengineered chitosan-modified FcRn-targeted porous silicon nanoparticles @ hypromellose 
acetate succinate for oral delivery of antidiabetic peptides, ACS Appl Mater Interfaces. 10 (2018) 44354-44367.

[14] J.P. Martins, R. D'Auria, D. Liu, F. Fontana, M.P.A. Ferreira, A. Correia, M. Kemell, K. Moslova, E. Makila, J. Salonen, L. Casettari, J. Hirvonen, B. Sarmento, H.A. Santos, Engineered multifunctional albumin-decorated porous silicon nanoparticles for FcRn translocation of insulin, Small. 14 (2018) e1800462.

[15] C. Azevedo, J. Nilsen, A. Grevys, R. Nunes, J.T. Andersen, B. Sarmento, Engineered albuminfunctionalized nanoparticles for improved FcRn binding enhance oral delivery of insulin, J Control Release. 327 (2020) 161-173.

[16] A. Goldin, J.A. Beckman, A.M. Schmidt, M.A. Creager, Advanced glycation end products: sparking the development of diabetic vascular injury, Circulation. 114 (2006) 597-605.

[17] S. Lamouille, J. Xu, R. Derynck, Molecular mechanisms of epithelial-mesenchymal transition, Nat Rev Mol Cell Biol. 15 (2014) 178-196.

[18] M.A. Yu, K.S. Shin, J.H. Kim, Y.I. Kim, S.S. Chung, S.H. Park, Y.L. Kim, D.H. Kang, HGF and BMP7 ameliorate high glucose-induced epithelial-to-mesenchymal transition of peritoneal mesothelium, J Am Soc Nephrol. 20 (2009) 567-581.

[19] M. Zeisberg, E.M. Zeisberg, Evidence for antifibrotic incretin-independent effects of the DPP-4 inhibitor linagliptin, Kidney Int. 88 (2015) 429-431.

[20] X. Wang, M. Hausding, S.Y. Weng, Y.O. Kim, S. Steven, T. Klein, A. Daiber, D. Schuppan, Gliptins suppress inflammatory macrophage activation to mitigate inflammation, fibrosis, oxidative stress, and vascular dysfunction in models of nonalcoholic steatohepatitis and liver fibrosis, Antioxid Redox Signal. 28 (2018) 87-109.

[21] J.P. Haymann, J.P. Levraud, S. Bouet, V. Kappes, J. Hagege, G. Nguyen, Y. Xu, E. Rondeau, J.D. Sraer, Characterization and localization of the neonatal Fc receptor in adult human kidney, J Am Soc Nephrol. 11 (2000) 632-639.

[22] G.M. Spiekermann, P.W. Finn, E.S. Ward, J. Dumont, B.L. Dickinson, R.S. Blumberg, W.I. Lencer, Receptor-mediated immunoglobulin $\mathrm{G}$ transport across mucosal barriers in adult life: functional expression of FcRn in the mammalian lung, J Exp Med. 196 (2002) 303-310.

[23] S. Akilesh, T.B. Huber, H. Wu, G. Wang, B. Hartleben, J.B. Kopp, J.H. Miner, D.C. Roopenian, E.R. Unanue, A.S. Shaw, Podocytes use FcRn to clear IgG from the glomerular basement membrane, Proc Natl Acad Sci USA. 105 (2008) 967-972.

[24] N.E. Simister, A.R. Rees, Isolation and characterization of an Fc receptor from neonatal rat small intestine, Eur J Immunol. 15 (1985) 733-738.

[25] N.E. Simister, K.E. Mostov, An Fc receptor structurally related to MHC class I antigens, Nature, 337 (1989) 184-187. 
[26] A.P. West, Jr., P.J. Bjorkman, Crystal structure and immunoglobulin $\mathrm{G}$ binding properties of the human major histocompatibility complex-related Fc receptor, Biochemistry. 39 (2000) 96989708.

[27] W.P. Burmeister, A.H. Huber, P.J. Bjorkman, Crystal structure of the complex of rat neonatal Fc receptor with Fc, Nature. 372 (1994) 379-383.

[28] P.J. Bjorkman, M.A. Saper, B. Samraoui, W.S. Bennett, J.L. Strominger, D.C. Wiley, The foreign antigen binding site and $T$ cell recognition regions of class I histocompatibility antigens, Nature. 329 (1987) 512-518.

[29] W.P. Burmeister, L.N. Gastinel, N.E. Simister, M.L. Blum, P.J. Bjorkman, Crystal structure at 2.2 A resolution of the MHC-related neonatal Fc receptor, Nature. 372 (1994) 336-343.

[30] M. Raghavan, V.R. Bonagura, S.L. Morrison, P.J. Bjorkman, Analysis of the $\mathrm{pH}$ dependence of the neonatal Fc receptor/immunoglobulin G interaction using antibody and receptor variants, Biochemistry. 34 (1995) 14649-14657.

[31] D.E. Vaughn, P.J. Bjorkman, Structural basis of pH-dependent antibody binding by the neonatal Fc receptor, Structure. 6 (1998) 63-73.

[32] C. Chaudhury, S. Mehnaz, J.M. Robinson, W.L. Hayton, D.K. Pearl, D.C. Roopenian, C.L. Anderson, The major histocompatibility complex-related Fc receptor for IgG (FcRn) binds albumin and prolongs its lifespan, J Exp Med. 197 (2003) 315-322.

[33] J.T. Andersen, J. Dee Qian, I. Sandlie, The conserved histidine 166 residue of the human neonatal Fc receptor heavy chain is critical for the $\mathrm{pH}$-dependent binding to albumin, Eur J Immunol. 36 (2006) 3044-3051.

[34] J.T. Andersen, B. Dalhus, J. Cameron, M.B. Daba, A. Plumridge, L. Evans, S.O. Brennan, K.S. Gunnarsen, M. Bjoras, D. Sleep, I. Sandlie, Structure-based mutagenesis reveals the albuminbinding site of the neonatal Fc receptor, Nat Commun. 3 (2012) 610.

[35] V. Oganesyan, M.M. Damschroder, K.E. Cook, Q. Li, C. Gao, H. Wu, W.F. Dall'Acqua, Structural insights into neonatal Fc receptor-based recycling mechanisms, J Biol Chem. 289 (2014) 7812-7824.

[36] M. Raghavan, V.R. Bonagura, S.L. Morrison, P.J. Bjorkman, Analysis of the pH dependence of the neonatal Fc receptor/immunoglobulin G interaction using antibody and receptor variants, Biochemistry. 34 (1995) 14649-14657.

[37] C. Chaudhury, C.L. Brooks, D.C. Carter, J.M. Robinson, C.L. Anderson, Albumin binding to FcRn: distinct from the FcRn-IgG interaction, Biochemistry. 45 (2006) 4983-4990.

[38] D.C. Roopenian, S. Akilesh, FcRn: the neonatal Fc receptor comes of age, Nat Rev Immunol. 7 (2007) 715. 
[39] K.M. Morrill, J. Polo, A. Lago, J. Campbell, J. Quigley, H. Tyler, Estimate of serum immunoglobulin $G$ concentration using refractometry with or without caprylic acid fractionation, J Dairy Sci. 96 (2013) 4535-4541.

[40] A. Gonzalez-Quintela, R. Alende, F. Gude, J. Campos, J. Rey, L.M. Meijide, C. FernandezMerino, C. Vidal, Serum levels of immunoglobulins (IgG, IgA, IgM) in a general adult population and their relationship with alcohol consumption, smoking and common metabolic abnormalities, Clin Exp Immunol. 151 (2008) 42-50.

[41] C.R. Jolliff, K.M. Cost, P.C. Stivrins, P.P. Grossman, C.R. Nolte, S.M. Franco, K.J. Fijan, L.L. Fletcher, H.C. Shriner, Reference intervals for serum IgG, IgA, IgM, C3, and C4 as determined by rate nephelometry, Clin Chem. 28 (1982) 126-128.

[42] W. van Muiswinkel, A. de Laat, J. Mink, A. van Oudenaren, R. Benner, Serum immunoglobulin levels in mice, Int Arch Allergy Immunol. 60 (1979) 240-248.

[43] S.W. de Taeye, T. Rispens, G. Vidarsson, The ligands for human IgG and their effector functions, Antibodies. 8 (2019).

[44] E.O. Saphire, P.W. Parren, R. Pantophlet, M.B. Zwick, G.M. Morris, P.M. Rudd, R.A. Dwek, R.L. Stanfield, D.R. Burton, I.A. Wilson, Crystal structure of a neutralizing human IGG against HIV1: a template for vaccine design, Science. 293 (2001) 1155-1159.

[45] J.K. Kim, M.F. Tsen, V. Ghetie, E.S. Ward, Localization of the site of the murine IgG1 molecule that is involved in binding to the murine intestinal Fc receptor, Eur J Immunol. 24 (1994) 24292434.

[46] J.K. Kim, M.F. Tsen, V. Ghetie, E.S. Ward, Identifying amino acid residues that influence plasma clearance of murine IgG1 fragments by site-directed mutagenesis, Eur J Immunol. 24 (1994) 542-548.

[47] M. Raghavan, M.Y. Chen, L.N. Gastinel, P.J. Bjorkman, Investigation of the interaction between the class I MHC-related Fc receptor and its immunoglobulin G ligand, Immunity, 1 (1994) 303-315.

[48] C. Medesan, D. Matesoi, C. Radu, V. Ghetie, E.S. Ward, Delineation of the amino acid residues involved in transcytosis and catabolism of mouse IgG1, J Immunol. 158 (1997) 22112217.

[49] J.K. Kim, M. Firan, C.G. Radu, C.H. Kim, V. Ghetie, E.S. Ward, Mapping the site on human IgG for binding of the MHC class I-related receptor, FcRn, Eur J Immunol. 29 (1999) 2819-2825.

[50] W.L. Martin, A.P. West, L. Gan, P.J. Bjorkman, Crystal Structure at $2.8 \AA$ of an FcRn/Heterodimeric Fc Complex, Mol Cell. 7 (2001) 867-877. 
[51] B.T. Walters, P.F. Jensen, V. Larraillet, K. Lin, T. Patapoff, T. Schlothauer, K.D. Rand, J. Zhang, Conformational destabilization of immunoglobulin $\mathrm{G}$ increases the low $\mathrm{pH}$ binding affinity with the neonatal Fc receptor, J Biol Chem. 291 (2016) 1817-1825.

[52] S. Foss, A. Grevys, K.M.K. Sand, M. Bern, P. Blundell, T.E. Michaelsen, R.J. Pleass, I. Sandlie, J.T. Andersen, Enhanced FcRn-dependent transepithelial delivery of IgG by Fc-engineering and polymerization, J Control Release. 223 (2016) 42-52.

[53] A.J. Bitonti, J.A. Dumont, S.C. Low, R.T. Peters, K.E. Kropp, V.J. Palombella, J.M. Stattel, Y. Lu, C.A. Tan, J.J. Song, A.M. Garcia, N.E. Simister, G.M. Spiekermann, W.I. Lencer, R.S. Blumberg, Pulmonary delivery of an erythropoietin Fc fusion protein in non-human primates through an immunoglobulin transport pathway, Proc Natl Acad Sci USA. 101 (2004) 9763-9768.

[54] C. Medesan, D. Matesoi, C. Radu, V. Ghetie, E.S. Ward, Delineation of the amino acid residues involved in transcytosis and catabolism of mouse IgG1, J Immunol. 158 (1997) 22112217.

[55] D.E. Vaughn, C.M. Milburn, D.M. Penny, W.L. Martin, J.L. Johnson, P.J. Bjorkman, Identification of critical IgG binding epitopes on the neonatal Fc receptor, J Mol Biol. 274 (1997) 597-607.

[56] N.M. Piche-Nicholas, L.B. Avery, A.C. King, M. Kavosi, M. Wang, D.M. O'Hara, L. Tchistiakova, M. Katragadda, Changes in complementarity-determining regions significantly alter IgG binding to the neonatal Fc receptor (FcRn) and pharmacokinetics, MAbs. 10 (2018) 81-94.

[57] W. Wang, P. Lu, Y. Fang, L. Hamuro, T. Pittman, B. Carr, J. Hochman, T. Prueksaritanont, Monoclonal antibodies with identical Fc sequences can bind to FcRn differentially with pharmacokinetic consequences, Drug Metab Dispos. 39 (2011) 1469-1477.

[58] A. Schoch, H. Kettenberger, O. Mundigl, G. Winter, J. Engert, J. Heinrich, T. Emrich, Chargemediated influence of the antibody variable domain on FcRn-dependent pharmacokinetics, Proc Natl Acad Sci USA. 112 (2015) 5997-6002.

[59] P.F. Jensen, V. Larraillet, T. Schlothauer, H. Kettenberger, M. Hilger, K.D. Rand, Investigating the interaction between the neonatal Fc receptor and monoclonal antibody variants by hydrogen/deuterium exchange mass spectrometry, Mol Cell Proteomics. 14 (2015) 148-161.

[60] J. Theodore Peters, All about albumin: Biochemistry, genetics, and medical applications. 1995.

[61] J. Zaias, M. Mineau, C. Cray, D. Yoon, N.H. Altman, Reference values for serum proteins of common laboratory rodent strains, J Am Assoc Lab Anim Sci. 48 (2009) 387-390.

[62] J. Ghuman, P.A. Zunszain, I. Petitpas, A.A. Bhattacharya, M. Otagiri, S. Curry, Structural basis of the drug-binding specificity of human serum albumin, J Mol Biol. 353 (2005) 38-52. 
[63] M. Bern, K.M. Sand, J. Nilsen, I. Sandlie, J.T. Andersen, The role of albumin receptors in regulation of albumin homeostasis: Implications for drug delivery, J Control Release. 211 (2015) 144-162.

[64] S. Curry, H. Mandelkow, P. Brick, N. Franks, Crystal structure of human serum albumin complexed with fatty acid reveals an asymmetric distribution of binding sites, Nat Struct Biol. 5 (1998) 827-835.

[65] M.M. Schmidt, S.A. Townson, A.J. Andreucci, B.M. King, E.B. Schirmer, A.J. Murillo, C. Dombrowski, A.W. Tisdale, P.A. Lowden, A.L. Masci, J.T. Kovalchin, D.V. Erbe, K.D. Wittrup, E.S. Furfine, T.M. Barnes, Crystal structure of an HSA/FcRn complex reveals recycling by competitive mimicry of HSA ligands at a pH-dependent hydrophobic interface, Structure. 21 (2013) 19661978.

[66] K.M. Sand, B. Dalhus, G.J. Christianson, M. Bern, S. Foss, J. Cameron, D. Sleep, M. Bjørås, D.C. Roopenian, I. Sandlie, J.T. Andersen, Dissection of the neonatal Fc receptor (FcRn)-albumin interface using mutagenesis and anti-FcRn albumin-blocking antibodies, J Biol Chem. 289 (2014) 17228-17239.

[67] K.M. Sand, M. Bern, J. Nilsen, B. Dalhus, K.S. Gunnarsen, J. Cameron, A. Grevys, K. Bunting, I. Sandlie, J.T. Andersen, Interaction with both domain I and III of albumin is required for optimal pH-dependent binding to the neonatal Fc receptor (FcRn), J Biol Chem. 289 (2014) 34583-34594. [68] M. Bern, J. Nilsen, M. Ferrarese, K.M.K. Sand, T.T. Gjølberg, H.E. Lode, R.J. Davidson, R.M. Camire, E.S. Bækkevold, S. Foss, A. Grevys, B. Dalhus, J. Wilson, L.S. Høydahl, G.J. Christianson, D.C. Roopenian, T. Schlothauer, T.E. Michaelsen, M.C. Moe, S. Lombardi, M. Pinotti, I. Sandlie, A. Branchini, J.T. Andersen, An engineered human albumin enhances half-life and transmucosal delivery when fused to protein-based biologics, Sci Transl Med. 12 (2020) eabb0580.

[69] T. Peters, Jr., Serum albumin, Adv Protein Chem. 37 (1985) 161-245.

[70] H.L. Spiegelberg, B.G. Fishkin, The catabolism of human G immunoglobulins of different heavy chain subclasses. 3 . The catabolism of heavy chain disease proteins and of Fc fragments of myeloma proteins, Clin Exp Immunol. 10 (1972) 599-607.

[71] T.A. Waldmann, W. Strober, Metabolism of immunoglobulins, Prog Allergy. 13 (1969) 1-110. [72] A. Grevys, J. Nilsen, K.M.K. Sand, M.B. Daba, I. Øynebråten, M. Bern, M.B. McAdam, S. Foss, T. Schlothauer, T.E. Michaelsen, G.J. Christianson, D.C. Roopenian, R.S. Blumberg, I. Sandlie, J.T. Andersen, A human endothelial cell-based recycling assay for screening of FcRn targeted molecules, Nat Commun. 9 (2018) 621.

[73] E.J. Israel, D.F. Wilsker, K.C. Hayes, D. Schoenfeld, N.E. Simister, Increased clearance of IgG in mice that lack beta 2-microglobulin: possible protective role of FcRn, Immunology. 89 (1996) 573-578. 
[74] D.C. Roopenian, G.J. Christianson, T.J. Sproule, A.C. Brown, S. Akilesh, N. Jung, S. Petkova, L. Avanessian, E.Y. Choi, D.J. Shaffer, P.A. Eden, C.L. Anderson, The MHC class I-like IgG receptor controls perinatal IgG transport, IgG homeostasis, and fate of IgG-Fc-coupled drugs, J Immunol. 170 (2003) 3528-3533.

[75] E.S. Ward, R.J. Ober, Chapter 4: Multitasking by exploitation of intracellular transport functions the many faces of FcRn, Adv Immunol. 103 (2009) 77-115.

[76] T.A. Waldmann, W.D. Terry, Familial hypercatabolic hypoproteinemia. A disorder of endogenous catabolism of albumin and immunoglobulin, J Clin Invest. 86 (1990) 2093-2098.

[77] M.A. Wani, L.D. Haynes, J. Kim, C.L. Bronson, C. Chaudhury, S. Mohanty, T.A. Waldmann, J.M. Robinson, C.L. Anderson, Familial hypercatabolic hypoproteinemia caused by deficiency of the neonatal Fc receptor, FcRn, due to a mutant beta2-microglobulin gene, Proc Natl Acad Sci USA. 103 (2006) 5084-5089.

[78] L.J. Blumberg, J.E. Humphries, S.D. Jones, L.B. Pearce, R. Holgate, A. Hearn, J. Cheung, A. Mahmood, B. Del Tito, J.S. Graydon, L.E. Stolz, A. Bitonti, S. Purohit, D. de Graaf, K. Kacena, J.T. Andersen, G.J. Christianson, D.C. Roopenian, J.J. Hubbard, A.K. Gandhi, K. Lasseter, M. Pyzik, R.S. Blumberg, Blocking FcRn in humans reduces circulating IgG levels and inhibits IgG immune complex-mediated immune responses, Sci Adv. 5 (2019) eaax9586.

[79] L.E. Ling, J.L. Hillson, R.G. Tiessen, T. Bosje, M.P. van lersel, D.J. Nix, L. Markowitz, N.A. Cilfone, J. Duffner, J.B. Streisand, A.M. Manning, S. Arroyo, M281, an Anti-FcRn antibody: Pharmacodynamics, pharmacokinetics, and safety across the full range of IgG reduction in a firstin-human study, Clin Pharmacol Ther. 105 (2019) 1031-1039.

[80] T. Robak, M. Kazmierczak, I. Jarque, V. Musteata, J. Trelinski, N. Cooper, P. Kiessling, U. Massow, F. Woltering, R. Snipes, J. Ke, G. Langdon, J.B. Bussel, S. Jolles, Phase 2 multiple-dose study of an FcRn inhibitor, rozanolixizumab, in patients with primary immune thrombocytopenia, Blood Adv. 4 (2020) 4136-4146.

[81] P. Ulrichts, A. Guglietta, T. Dreier, T. van Bragt, V. Hanssens, E. Hofman, B. Vankerckhoven, P. Verheesen, N. Ongenae, V. Lykhopiy, F.J. Enriquez, J. Cho, R.J. Ober, E.S. Ward, H. de Haard, N. Leupin, Neonatal Fc receptor antagonist efgartigimod safely and sustainably reduces IgGs in humans, J Clin Invest. 128 (2018) 4372-4386.

[82] R.J. Ober, C. Martinez, C. Vaccaro, J. Zhou, E.S. Ward, Visualizing the site and dynamics of IgG salvage by the MHC class I-related receptor, FcRn, J Immunol. 172 (2004) 2021-2029.

[83] M. Pyzik, T. Rath, T.T. Kuo, S. Win, K. Baker, J.J. Hubbard, R. Grenha, A. Gandhi, T.D. Kramer, A.R. Mezo, Z.S. Taylor, K. McDonnell, V. Nienaber, J.T. Andersen, A. Mizoguchi, L. Blumberg, S. Purohit, S.D. Jones, G. Christianson, W.I. Lencer, I. Sandlie, N. Kaplowitz, D.C. Roopenian, R.S. 
Blumberg, Hepatic FcRn regulates albumin homeostasis and susceptibility to liver injury, Proc Natl Acad Sci USA. 114 (2017) E2862-e2871.

[84] E.G.W. Schmidt, M.L. Hvam, F. Antunes, J. Cameron, D. Viuff, B. Andersen, N.N. Kristensen, K.A. Howard, Direct demonstration of a neonatal Fc receptor ( $F c R n)$-driven endosomal sorting pathway for cellular recycling of albumin, J Biol Chem. 292 (2017) 13312-13322.

[85] Z. Gan, S. Ram, R.J. Ober, E.S. Ward, Using multifocal plane microscopy to reveal novel trafficking processes in the recycling pathway, J Cell Sci. 126 (2013) 1176-1188.

[86] Z. Gan, S. Ram, C. Vaccaro, R.J. Ober, E.S. Ward, Analyses of the recycling receptor, FcRn, in live cells reveal novel pathways for lysosomal delivery, Traffic. 10 (2009) 600-614.

[87] R.J. Ober, C. Martinez, X. Lai, J. Zhou, E.S. Ward, Exocytosis of IgG as mediated by the receptor, FcRn: an analysis at the single-molecule level, Proc Natl Acad Sci USA. 101 (2004) 11076-11081.

[88] P. Prabhat, Z. Gan, J. Chao, S. Ram, C. Vaccaro, S. Gibbons, R.J. Ober, E.S. Ward, Elucidation of intracellular recycling pathways leading to exocytosis of the Fc receptor, FcRn, by using multifocal plane microscopy, Proc Natl Acad Sci. 104 (2007) 5889-5894.

[89] E.S. Ward, C. Martinez, C. Vaccaro, J. Zhou, Q. Tang, R.J. Ober, From sorting endosomes to exocytosis: association of Rab4 and Rab11 GTPases with the Fc receptor, FcRn, during recycling, Mol Biol Cell. 16 (2005) 2028-2038.

[90] E.S. Ward, J. Zhou, V. Ghetie, R.J. Ober, Evidence to support the cellular mechanism involved in serum IgG homeostasis in humans, Int Immunol. 15 (2003) 187-195.

[91] A.W. Weflen, N. Baier, Q.J. Tang, M. Van den Hof, R.S. Blumberg, W.I. Lencer, R.H. Massol, Multivalent immune complexes divert FcRn to lysosomes by exclusion from recycling sorting tubules, Mol Biol Cell. 24 (2013) 2398-2405.

[92] J. Chia, J. Louber, I. Glauser, S. Taylor, G.T. Bass, S.K. Dower, P.A. Gleeson, A.M. Verhagen, Half-life-extended recombinant coagulation factor IX-albumin fusion protein is recycled via the FcRn-mediated pathway, J Biol Chem. 293 (2018) 6363-6373.

[93] S. Akilesh, G.J. Christianson, D.C. Roopenian, A.S. Shaw, Neonatal FcR expression in bone marrow-derived cells functions to protect serum IgG from catabolism, J Immunol. 179 (2007) 4580-4588.

[94] H.P. Montoyo, C. Vaccaro, M. Hafner, R.J. Ober, W. Mueller, E.S. Ward, Conditional deletion of the MHC class I-related receptor FcRn reveals the sites of IgG homeostasis in mice, Proc Natl Acad Sci USA. 106 (2009) 2788-2793.

[95] M. Sarav, Y. Wang, B.K. Hack, A. Chang, M. Jensen, L. Bao, R.J. Quigg, Renal FcRn reclaims albumin but facilitates elimination of IgG, J Am Soc Nephrol. 20 (2009) 1941-1952. 
[96] K. Kobayashi, S.W. Qiao, M. Yoshida, K. Baker, W.I. Lencer, R.S. Blumberg, An FcRndependent role for anti-flagellin immunoglobulin $G$ in pathogenesis of colitis in mice, Gastroenterology. 137 (2009) 1746-1756 e1741.

[97] V. Tenten, S. Menzel, U. Kunter, E.M. Sicking, C.R. van Roeyen, S.K. Sanden, M. Kaldenbach, P. Boor, A. Fuss, S. Uhlig, R. Lanzmich, B. Willemsen, H. Dijkman, M. Grepl, K. Wild, W. Kriz, B. Smeets, J. Floege, M.J. Moeller, Albumin is recycled from the primary urine by tubular transcytosis, J Am Soc Nephrol. 24 (2013) 1966-1980.

[98] D.K. Challa, X. Wang, H.P. Montoyo, R. Velmurugan, R.J. Ober, E.S. Ward, Neonatal Fc receptor expression in macrophages is indispensable for IgG homeostasis, MAbs. 11 (2019) 848860.

[99] K.H. Aaen, A.K. Anthi, I. Sandlie, J. Nilsen, S. Mester, J.T. Andersen, The neonatal Fc receptor in mucosal immune regulation, Scand J Immunol. (2020) e13017.

[100] T.T. Kuo, K. Baker, M. Yoshida, S.-W. Qiao, V.G. Aveson, W.I. Lencer, R.S. Blumberg, Neonatal Fc receptor: From immunity to therapeutics, J Clin Immunol. 30 (2010) 777-789.

[101] M. Yoshida, S.M. Claypool, J.S. Wagner, E. Mizoguchi, A. Mizoguchi, D.C. Roopenian, W.I. Lencer, R.S. Blumberg, Human neonatal Fc receptor mediates transport of IgG into luminal secretions for delivery of antigens to mucosal dendritic cells, Immunity. 20 (2004) 769-783.

[102] B.L. Dickinson, K. Badizadegan, Z. Wu, J.C. Ahouse, X. Zhu, N.E. Simister, R.S. Blumberg, W.I. Lencer, Bidirectional FcRn-dependent IgG transport in a polarized human intestinal epithelial cell line, J Clin Invest. 104 (1999) 903-911.

[103] K.M. McCarthy, Y. Yoong, N.E. Simister, Bidirectional transcytosis of IgG by the rat neonatal Fc receptor expressed in a rat kidney cell line: a system to study protein transport across epithelia, J Cell Sci. 113 ( Pt 7) (2000) 1277-1285.

[104] S.M. Claypool, B.L. Dickinson, M. Yoshida, W.I. Lencer, R.S. Blumberg, Functional reconstitution of human FcRn in Madin-Darby canine kidney cells requires co-expressed human beta 2-microglobulin, J Biol Chem. 277 (2002) 28038-28050.

[105] M. Yoshida, K. Kobayashi, T.T. Kuo, L. Bry, J.N. Glickman, S.M. Claypool, A. Kaser, T. Nagaishi, D.E. Higgins, E. Mizoguchi, Y. Wakatsuki, D.C. Roopenian, A. Mizoguchi, W.I. Lencer, R.S. Blumberg, Neonatal Fc receptor for IgG regulates mucosal immune responses to luminal bacteria, J Clin Invest. 116 (2006) 2142-2151.

[106] S. Tzaban, R.H. Massol, E. Yen, W. Hamman, S.R. Frank, L.A. Lapierre, S.H. Hansen, J.R. Goldenring, R.S. Blumberg, W.I. Lencer, The recycling and transcytotic pathways for IgG transport by FcRn are distinct and display an inherent polarity, J Cell Biol. 185 (2009) 673-684. 
[107] Z. Li, S. Palaniyandi, R. Zeng, W. Tuo, D.C. Roopenian, X. Zhu, Transfer of IgG in the female genital tract by $\mathrm{MHC}$ class I-related neonatal Fc receptor ( $\mathrm{FcRn}$ ) confers protective immunity to vaginal infection, Proc Natl Acad Sci USA. 108 (2011) 4388-4393.

[108] P.J. Hornby, P.R. Cooper, C. Kliwinski, E. Ragwan, J.R. Mabus, B. Harman, S. Thompson, A.L. Kauffman, Z. Yan, S.H. Tam, H. Dorai, G.D. Powers, J. Giles-Komar, Human and non-human primate intestinal FcRn expression and immunoglobulin G transcytosis, Pharm Res. 31 (2014) 908-922.

[109] T. Rath, T.T. Kuo, K. Baker, S.W. Qiao, K. Kobayashi, M. Yoshida, D. Roopenian, E. Fiebiger, W.I. Lencer, R.S. Blumberg, The immunologic functions of the neonatal Fc receptor for IgG, J Clin Immunol. 33 Suppl 1 (2013) S9-17.

[110] D.J. Drucker, A. Dritselis, P. Kirkpatrick, Liraglutide, Nat Rev Drug Discov. 9 (2010) 267-268.

[111] B. Elsadek, F. Kratz, Impact of albumin on drug delivery - New applications on the horizon, J Control Release. 157 (2012) 4-28.

[112] S.E. Alavi, P.J. Cabot, P.M. Moyle, Glucagon-Like Peptide-1 Receptor agonists and strategies to improve their efficiency, Mol Pharm. 16 (2019) 2278-2295.

[113] E. Sebokova, A.D. Christ, H. Wang, S. Sewing, J.Z. Dong, J. Taylor, M.A. Cawthorne, M.D. Culler, Taspoglutide, an analog of human glucagon-like Peptide-1 with enhanced stability and in vivo potency, Endocrinology. 151 (2010) 2474-2482.

[114] C. Kapitza, T. Heise, P. Birman, K. Jallet, J. Ramis, R. Balena, Pharmacokinetic and pharmacodynamic properties of taspoglutide, a once-weekly, human GLP-1 analogue, after single-dose administration in patients with type 2 diabetes, Diabet Med. 26 (2009) 1156-1164. [115] J. Rosenstock, B. Balas, B. Charbonnel, G.B. Bolli, M. Boldrin, R. Ratner, R. Balena, T.e.S. Group, The fate of taspoglutide, a weekly GLP-1 receptor agonist, versus twice-daily exenatide for type 2 diabetes: the T-emerge 2 trial, Diabetes Care. 36 (2013) 498-504.

[116] EMA, Levemir (insulin detemir). Available online on: https://ec.europa.eu/health/documents/community-register/2010/2010033077668/anx 7766 8 en.pdf [accessed on $24^{\text {th }}$ november 2020].

[117] P. Home, P. Kurtzhals, Insulin detemir: From concept to clinical experience, Exp Opin pharmacotherapy, 7 (2006) 325-343.

[118] M. Rendell, Insulin degludec: A long-acting modern insulin analogue with a predictable pharmacokinetic/ pharmacodynamic profile, Drugs Today. 49 (2013) 387-397.

[119] NovoNordisk, Tresiba $^{\circledR}$ FlexTouch ${ }^{\oplus} 100 \mathrm{U} / \mathrm{mL}$. Available online on: https://www.novonordisk.com.br/content/dam/brazil/affiliate/www-novonordisk-br/Bulas/ Profissionais/Tresiba-FlexTouch bula-profissional.pdf [Accessed on $24^{\text {th }}$ november 2020]. 
[120] B. Elsadek, F. Kratz, Impact of albumin on drug delivery--new applications on the horizon, J Control Release. 157 (2012) 4-28.

[121] F. Wang, J.M. Carabino, C.M. Vergara, Insulin glargine: A systematic review of a long-acting insulin analogue, Clin Ther. 25 (2003) 1541-1577.

[122] J. Rosenstock, H.S. Bajaj, A. Janez, R. Silver, K. Begtrup, M.V. Hansen, T. Jia, R. Goldenberg, N.N. Investigators, Once-weekly insulin for type 2 diabetes without previous insulin treatment, N Engl J Med. 383 (2020) 2107-2116.

[123] U. HÖvelmann, L. Brøndsted, N.R. Kristensen, R. Ribel-Madsen, J.H. Devries, T.I.M. Heise, H. Haahr, 237-OR: Insulin Icodec: An insulin analog suited for once-weekly dosing in type 2 diabetes, Diabetes. 69 (2020).

[124] S.L. Anderson, T.R. Beutel, J.M. Trujillo, Oral semaglutide in type 2 diabetes, J Diabetes Complications. 34 (2020) 107520.

[125] T.A. Baekdal, M. Thomsen, V. Kupcova, C.W. Hansen, T.W. Anderson, Pharmacokinetics, safety, and tolerability of oral semaglutide in subjects with hepatic impairment, J Clin Pharmacol. 58 (2018) 1314-1323.

[126] C. Granhall, F.L. Sondergaard, M. Thomsen, T.W. Anderson, Pharmacokinetics, safety and tolerability of oral semaglutide in subjects with renal impairment, Clin Pharmacokinet. 57 (2018) 1571-1580.

[127] S. Dhillon, Semaglutide: First global approval, Drugs. 78 (2018) 275-284.

[128] K.K. Blakely, K. Weaver, Semaglutide is a new once-daily oral medication to treat type 2 diabetes, Nurs Womens Health. 24 (2020) 370-376.

[129] A.M. Semenya, S.A. Wilson, Oral semaglutide (Rybelsus) for the treatment of type 2 diabetes mellitus, Am Fam Physician. 102 (2020) 627-628.

[130] M. Husain, A.L. Birkenfeld, M. Donsmark, K. Dungan, F.G. Eliaschewitz, D.R. Franco, O.K. Jeppesen, I. Lingvay, O. Mosenzon, S.D. Pedersen, C.J. Tack, M. Thomsen, T. Vilsboll, M.L. Warren, S.C. Bain, P. Investigators, oral semaglutide and cardiovascular outcomes in patients with type 2 diabetes, N Engl J Med. 381 (2019) 841-851.

[131] O. Mosenzon, E.M. Miller, M.L. Warren, Oral semaglutide in patients with type 2 diabetes and cardiovascular disease, renal impairment, or other comorbidities, and in older patients, Postgrad Med. 132 (2020) 37-47.

[132] I.B. Halberg, K. Lyby, K. Wassermann, T. Heise, E. Zijlstra, L. Plum-Morschel, Efficacy and safety of oral basal insulin versus subcutaneous insulin glargine in type 2 diabetes: a randomised, double-blind, phase 2 trial, Lancet Diabetes Endocrinol. 7 (2019) 179-188.

[133] F. Hubalek, H.H.F. Refsgaard, S. Gram-Nielsen, P. Madsen, E. Nishimura, M. Munzel, C.L. Brand, C.E. Stidsen, C.H. Claussen, E.M. Wulff, L. Pridal, U. Ribel, J. Kildegaard, T. Porsgaard, E. 
Johansson, D.B. Steensgaard, L. Hovgaard, T. Glendorf, B.F. Hansen, M.K. Jensen, P.K. Nielsen, S. Ludvigsen, S. Rugh, P.W. Garibay, M.C. Moore, A.D. Cherrington, T. Kjeldsen, Molecular engineering of safe and efficacious oral basal insulin, Nat Commun. 11 (2020) 3746.

[134] T.W. Leonard, J. Lynch, M.J. McKenna, D.J. Brayden, Promoting absorption of drugs in humans using medium-chain fatty acid-based solid dosage forms: GIPET, Exp Opin Drug Deliv. 3 (2006) 685-692.

[135] R. Leger, K. Thibaudeau, M. Robitaille, O. Quraishi, P. van Wyk, N. Bousquet-Gagnon, J. Carette, J.P. Castaigne, D.P. Bridon, Identification of CJC-1131-albumin bioconjugate as a stable and bioactive GLP-1(7-36) analog, Bioorg Med Chem Lett. 14 (2004) 4395-4398.

[136] L.L. Baggio, Q. Huang, X. Cao, D.J. Drucker, An albumin-exendin-4 conjugate engages central and peripheral circuits regulating murine energy and glucose homeostasis, Gastroenterology. 134 (2008) 1137-1147.

[137] J.G. Kim, L.L. Baggio, D.P. Bridon, J.P. Castaigne, M.F. Robitaille, L. Jette, C. Benquet, D.J. Drucker, Development and characterization of a glucagon-like peptide 1-albumin conjugate: the ability to activate the glucagon-like peptide 1 receptor in vivo, Diabetes. 52 (2003) 751-759.

[138] R. Fan, Z. Kang, L. He, J. Chan, G. Xu, Exendin-4 improves blood glucose control in both young and aging normal non-diabetic mice, possible contribution of beta cell independent effects, PLoS One. 6 (2011) e20443.

[139] N. Giannoukakis, CJC-1131. ConjuChem, Cur Opin Investig Drugs. 4 (2003) 1245-1249.

[140] D. Pilati, K.A. Howard, Albumin-based drug designs for pharmacokinetic modulation, Expert Opin Drug Metab Toxicol. 16 (2020) 783-795.

[141] ConjuChem, PC-DAC ${ }^{\mathrm{TM}}$ : Insulin. Available online on: http://www.conjuchem.com/pipeline/ pc-dac-insulin [Accessed on $24^{\text {th }}$ november 2020].

[142] V. Oganesyan, M.M. Damschroder, K.E. Cook, Q. Li, C. Gao, H. Wu, W.F. Dall'Acqua, Structural insights into neonatal Fc receptor-based recycling mechanisms, J Biol Chem. 289 (2014) 7812-7824.

[143] J.T. Bukrinski, P. Sonderby, F. Antunes, B. Andersen, E.G.W. Schmidt, G.H.J. Peters, P. Harris, Glucagon-like peptide 1 conjugated to recombinant human serum albumin variants with modified neonatal Fc receptor binding properties. Impact on molecular structure and half-life, Biochemistry. 56 (2017) 4860-4870.

[144] J. Schmokel, A. Voldum, G. Tsakiridou, M. Kuhlmann, J. Cameron, E.S. Sorensen, J. Wengel, K.A. Howard, Site-selective conjugation of an anticoagulant aptamer to recombinant albumins and maintenance of neonatal Fc receptor binding, Nanotechnology. 28 (2017) 204004. 
[145] S.S. Petersen, E. Klaning, M.F. Ebbesen, B. Andersen, J. Cameron, E.S. Sorensen, K.A. Howard, Neonatal Fc receptor binding tolerance toward the covalent conjugation of payloads to cysteine 34 of human albumin variants, Mol Pharm. 13 (2016) 677-682.

[146] M.S. Rendell, Albiglutide: A unique GLP-1 receptor agonist, Expert Opin Biol Ther. 16 (2016) 1557-1569.

[147] R.M. Poole, M.L. Nowlan, Albiglutide: first global approval, Drugs. 74 (2014) 929-938.

[148] L.L. Baggio, Q. Huang, T.J. Brown, D.J. Drucker, A recombinant human glucagon-like peptide (GLP)-1-albumin protein (albugon) mimics peptidergic activation of GLP-1 receptordependent pathways coupled with satiety, gastrointestinal motility, and glucose homeostasis, Diabetes. 53 (2004) 2492-2500.

[149] J. Nilsen, E. Trabjerg, A. Grevys, C. Azevedo, S.O. Brennan, M. Stensland, J. Wilson, K.M.K. Sand, M. Bern, B. Dalhus, D.C. Roopenian, I. Sandlie, K.D. Rand, J.T. Andersen, An intact Cterminal end of albumin is required for its long half-life in humans, Commun Biol. 3 (2020) 181. [150] E. Jimenez-Solem, M.H. Rasmussen, M. Christensen, F.K. Knop, Dulaglutide, a long-acting GLP-1 analog fused with an Fc antibody fragment for the potential treatment of type 2 diabetes, Cur Opin Mol Ther. 12 (2010) 790-797.

[151] M. Sanford, Dulaglutide: First global approval, Drugs. 74 (2014) 2097-2103.

[152] R.M. Lu, Y.C. Hwang, I.J. Liu, C.C. Lee, H.Z. Tsai, H.J. Li, H.C. Wu, Development of therapeutic antibodies for the treatment of diseases, J Biomed Sci. 27 (2020) 1.

[153] T. Rath, K. Baker, J.A. Dumont, R.T. Peters, H. Jiang, S.W. Qiao, W.I. Lencer, G.F. Pierce, R.S. Blumberg, Fc-fusion proteins and FcRn: Structural insights for longer-lasting and more effective therapeutics, Crit Rev Biotechnol. 35 (2015) 235-254.

[154] W.F.D. Acqua, R.M. Woods, E.S. Ward, S.R. Palaszynski, N.K. Patel, Y.A. Brewah, H. Wu, P.A. Kiener, S. Langermann, Increasing the affinity of a human IgG1 for the neonatal Fc receptor: Biological consequences, J Immunol. 169 (2002) 5171.

[155] E.S. Ward, R.J. Ober, Targeting FcRn to generate antibody-based therapeutics, Trends Pharmacol Sci. 39 (2018) 892-904.

[156] R.-M. Lu, Y.-C. Hwang, I.J. Liu, C.-C. Lee, H.-Z. Tsai, H.-J. Li, H.-C. Wu, Development of therapeutic antibodies for the treatment of diseases, J Biomed Sci. 27 (2020) 1.

[157] P.J. Carter, G.A. Lazar, Next generation antibody drugs: pursuit of the 'high-hanging fruit', Nat Rev Drug Discov. 17 (2018) 197-223.

[158] B. Keymeulen, A. van Maurik, D. Inman, J. Oliveira, R. McLaughlin, R.M. Gittelman, B.O. Roep, P. Gillard, R. Hilbrands, F. Gorus, C. Mathieu, U. Van de Velde, N. Wisniacki, A. Napolitano, A randomised, single-blind, placebo-controlled, dose-finding safety and tolerability study of the 
anti-CD3 monoclonal antibody otelixizumab in new-onset type 1 diabetes, Diabetologia. 64 (2021) 313-324.

[159] J.T. Andersen, B. Dalhus, D. Viuff, B.T. Ravn, K.S. Gunnarsen, A. Plumridge, K. Bunting, F. Antunes, R. Williamson, S. Athwal, E. Allan, L. Evans, M. Bjørås, S. Kjærulff, D. Sleep, I. Sandlie, J. Cameron, Extending serum half-life of albumin by engineering neonatal Fc receptor ( $F \mathrm{CRn}$ ) binding, J Biol Chem. 289 (2014) 13492-13502.

[160] A.R. Mezo, K.A. McDonnell, A. Castro, C. Fraley, Structure-activity relationships of a peptide inhibitor of the human FcRn:human IgG interaction, Bioorg Med Chem. 16 (2008) 63946405.

[161] A.R. Mezo, K.A. McDonnell, C.A. Hehir, S.C. Low, V.J. Palombella, J.M. Stattel, G.D. Kamphaus, C. Fraley, Y. Zhang, J.A. Dumont, A.J. Bitonti, Reduction of IgG in nonhuman primates by a peptide antagonist of the neonatal Fc receptor FcRn, Proc Natl Acad Sci USA. 105 (2008) 2337-2342.

[162] J. Seijsing, M. Lindborg, I. Höidén-Guthenberg, H. Bönisch, E. Guneriusson, F.Y. Frejd, L. Abrahmsén, C. Ekblad, J. Löfblom, M. Uhlén, T. Gräslund, An engineered affibody molecule with $\mathrm{pH}$-dependent binding to FcRn mediates extended circulatory half-life of a fusion protein, Proc Natl Acad Sci USA. 111 (2014) 17110-17115.

[163] T. Ying, Y. Wang, Y. Feng, P. Prabakaran, R. Gong, L. Wang, K. Crowder, D.S. Dimitrov, Engineered antibody domains with significantly increased transcytosis and half-life in macaques mediated by FcRn, MAbs. 7 (2015) 922-930.

[164] Y. Qiu, W. Lv, M. Xu, Y. Xu, Single chain antibody fragments with $\mathrm{pH}$ dependent binding to FcRn enabled prolonged circulation of therapeutic peptide in vivo, J Control Release. 229 (2016) $37-47$.

[165] M.J. Borrok, Y. Wu, N. Beyaz, X.Q. Yu, V. Oganesyan, W.F. Dall'Acqua, P. Tsui, pHdependent binding engineering reveals an FcRn affinity threshold that governs IgG recycling, J Biol Chem. 290 (2015) 4282-4290.

[166] Y.A. Yeung, M.K. Leabman, J.S. Marvin, J. Qiu, C.W. Adams, S. Lien, M.A. Starovasnik, H.B. Lowman, Engineering human IgG1 affinity to human neonatal Fc receptor: impact of affinity improvement on pharmacokinetics in primates, J Immunol. 182 (2009) 7663-7671.

[167] V. Ghetie, S. Popov, J. Borvak, C. Radu, D. Matesoi, C. Medesan, R.J. Ober, E.S. Ward, Increasing the serum persistence of an IgG fragment by random mutagenesis, Nat Biotechnol. 15 (1997) 637-640.

[168] W.F. Dall'Acqua, P.A. Kiener, H. Wu, Properties of human IgG1s engineered for enhanced binding to the neonatal Fc receptor (FcRn), J Biol Chem. 281 (2006) 23514-23524. 
[169] G.J. Robbie, R. Criste, W.F. Dall'acqua, K. Jensen, N.K. Patel, G.A. Losonsky, M.P. Griffin, A novel investigational Fc-modified humanized monoclonal antibody, motavizumab-YTE, has an extended half-life in healthy adults, Antimicrob Agents Chemother. 57 (2013) 6147-6153.

[170] J. Zalevsky, A.K. Chamberlain, H.M. Horton, S. Karki, I.W.L. Leung, T.J. Sproule, G.A. Lazar, D.C. Roopenian, J.R. Desjarlais, Enhanced antibody half-life improves in vivo activity, Nat Biotechnol. 28 (2010) 157-159.

[171] R. Gautam, Y. Nishimura, A. Pegu, M.C. Nason, F. Klein, A. Gazumyan, J. Golijanin, A. Buckler-White, R. Sadjadpour, K. Wang, Z. Mankoff, S.D. Schmidt, J.D. Lifson, J.R. Mascola, M.C. Nussenzweig, M.A. Martin, A single injection of anti-HIV-1 antibodies protects against repeated SHIV challenges, Nature. 533 (2016) 105-109.

[172] S.Y. Ko, A. Pegu, R.S. Rudicell, Z.Y. Yang, M.G. Joyce, X. Chen, K. Wang, S. Bao, T.D. Kraemer, T. Rath, M. Zeng, S.D. Schmidt, J.P. Todd, S.R. Penzak, K.O. Saunders, M.C. Nason, A.T. Haase, S.S. Rao, R.S. Blumberg, J.R. Mascola, G.J. Nabel, Enhanced neonatal Fc receptor function improves protection against primate SHIV infection, Nature. 514 (2014) 642-645.

[173] M.R. Gaudinski, E.E. Coates, K.V. Houser, G.L. Chen, G. Yamshchikov, J.G. Saunders, L.A. Holman, I. Gordon, S. Plummer, C.S. Hendel, M. Conan-Cibotti, M.G. Lorenzo, S. Sitar, K. Carlton, C. Laurencot, R.T. Bailer, S. Narpala, A.B. McDermott, A.M. Namboodiri, J.P. Pandey, R.M. Schwartz, Z. Hu, R.A. Koup, E. Capparelli, B.S. Graham, J.R. Mascola, J.E. Ledgerwood, V.R.C.S. Team, Safety and pharmacokinetics of the Fc-modified HIV-1 human monoclonal antibody VRC01LS: A Phase 1 open-label clinical trial in healthy adults, PLoS Med. 15 (2018) e1002493.

[174] M.R. Gaudinski, K.V. Houser, N.A. Doria-Rose, G.L. Chen, R.S.S. Rothwell, N. Berkowitz, P. Costner, L.A. Holman, I.J. Gordon, C.S. Hendel, F. Kaltovich, M. Conan-Cibotti, M. Gomez Lorenzo, C. Carter, S. Sitar, K. Carlton, J. Gall, C. Laurencot, B.C. Lin, R.T. Bailer, A.B. McDermott, S.Y. Ko, A. Pegu, Y.D. Kwon, P.D. Kwong, A.M. Namboodiri, J.P. Pandey, R. Schwartz, F. Arnold, Z. Hu, L. Zhang, Y. Huang, R.A. Koup, E.V. Capparelli, B.S. Graham, J.R. Mascola, J.E. Ledgerwood, V.R.C.S. team, Safety and pharmacokinetics of broadly neutralising human monoclonal antibody VRC07-523LS in healthy adults: a phase 1 dose-escalation clinical trial, Lancet HIV. 6 (2019) e667e679.

[175] R. Deng, K.M. Loyet, S. Lien, S. Iyer, L.E. DeForge, F.-P. Theil, H.B. Lowman, P.J. Fielder, S. Prabhu, Pharmacokinetics of humanized monoclonal anti-tumor necrosis factor- $\alpha$ antibody and its neonatal Fc receptor variants in mice and cynomolgus monkeys, Drug Metab Dispos. 38 (2010) 600-605.

[176] M.J. Borrok, N. Mody, X. Lu, M.L. Kuhn, H. Wu, W.F. Dall'Acqua, P. Tsui, An "Fc-silenced" IgG1 format with extended half-life designed for improved stability, J Pharm Sci. 106 (2017) 1008-1017. 
[177] P.R. Hinton, J.M. Xiong, M.G. Johlfs, M.T. Tang, S. Keller, N. Tsurushita, An engineered human IgG1 antibody with longer serum half-life, J Immunol. 176 (2006) 346.

[178] A. Datta-Mannan, C.K. Chow, C. Dickinson, D. Driver, J. Lu, D.R. Witcher, V.J. Wroblewski, FcRn affinity-pharmacokinetic relationship of five human IgG4 antibodies engineered for improved in vitro FcRn binding properties in cynomolgus monkeys, Drug Metab Dispos. 40 (2012) 1545-1555.

[179] P.R. Hinton, M.G. Johlfs, J.M. Xiong, K. Hanestad, K.C. Ong, C. Bullock, S. Keller, M.T. Tang, J.Y. Tso, M. Vasquez, N. Tsurushita, Engineered human IgG antibodies with longer serum halflives in primates, J Biol Chem. 279 (2004) 6213-6216.

[180] C. Monnet, S. Jorieux, N. Souyris, O. Zaki, A. Jacquet, N. Fournier, F. Crozet, C. de Romeuf, K. Bouayadi, R. Urbain, C.K. Behrens, P. Mondon, A. Fontayne, Combined glyco- and protein-Fc engineering simultaneously enhance cytotoxicity and half-life of a therapeutic antibody, MAbs. 6 (2014) 422-436.

[181] S.B. Petkova, S. Akilesh, T.J. Sproule, G.J. Christianson, H. Al Khabbaz, A.C. Brown, L.G. Presta, Y.G. Meng, D.C. Roopenian, Enhanced half-life of genetically engineered human IgG1 antibodies in a humanized FcRn mouse model: potential application in humorally mediated autoimmune disease, Int Immunol. 18 (2006) 1759-1769.

[182] I. Van de Walle, K. Silence, K. Budding, L. Van de Ven, K. Dijkxhoorn, E. de Zeeuw, C. Yildiz, S. Gabriels, J.M. Percier, J. Wildemann, J. Meeldijk, P.J. Simons, L. Boon, L. Cox, R. Holgate, R. Urbanus, H.G. Otten, J.H.W. Leusen, C. Blanchetot, H. de Haard, C.E. Hack, P. Boross, ARGX-117, a therapeutic complement inhibiting antibody targeting C2, J Allergy Clin Immunol. (2020).

[183] B.C. Mackness, J.A. Jaworski, E. Boudanova, A. Park, D. Valente, C. Mauriac, O. Pasquier, T. Schmidt, M. Kabiri, A. Kandira, K. Radošević, H. Qiu, Antibody Fc engineering for enhanced neonatal Fc receptor binding and prolonged circulation half-life, MAbs. 11 (2019) 1276-1288.

[184] C.-H. Lee, T.H. Kang, O. Godon, M. Watanabe, G. Delidakis, C.M. Gillis, D. Sterlin, D. Hardy, M. Cogné, L.E. Macdonald, A.J. Murphy, N. Tu, J. Lee, J.R. McDaniel, E. Makowski, P.M. Tessier, A.S. Meyer, P. Bruhns, G. Georgiou, An engineered human Fc domain that behaves like a pHtoggle switch for ultra-long circulation persistence, Nat Commun. 10 (2019) 5031.

[185] M.J. Bernett, S.Y. Chu, I. Leung, G.L. Moore, S.H. Lee, E. Pong, H. Chen, S. Phung, U.S. Muchhal, H.M. Horton, G.A. Lazar, J.R. Desjarlais, D.E. Szymkowski, Immune suppression in cynomolgus monkeys by XPro9523: An improved CTLA4-Ig fusion with enhanced binding to CD80, CD86 and neonatal Fc receptor FcRn, MAbs. 5 (2013) 384-396.

[186] J. Douthwaite, J. Moisan, C. Privezentzev, B. Soskic, S. Sabbah, S. Cohen, A. Collinson, E. England, C. Huntington, B. Kemp, L. Zhuang, S. Hudak, D.G. Rees, D. Goldberg, C. Barton, L. Chang, I. Vainshtein, M. Liang, L. Iciek, P. Ambery, M. Peakman, T.J. Vaughan, T.I.M. Tree, D.M. 
Sansom, M.A. Bowen, R.R. Minter, L. Jermutus, Correction: A CD80-biased CTLA4-Ig fusion protein with superior in vivo efficacy by simultaneous engineering of affinity, selectivity, stability, and FcRn binding, J Immunol. 199 (2017) 1943.

[187] S. Krapp, Y. Mimura, R. Jefferis, R. Huber, P. Sondermann, Structural analysis of human IgG-Fc glycoforms reveals a correlation between glycosylation and structural integrity, J Mol Biol. 325 (2003) 979-989.

[188] S. Sugio, A. Kashima, S. Mochizuki, M. Noda, K. Kobayashi, Crystal structure of human serum albumin at 2.5 A resolution, Protein Eng. 12 (1999) 439-446.

[189] H.A.D. Lagasse, H. Hengel, B. Golding, Z.E. Sauna, Fc-fusion drugs have Fc gammaR/C1q binding and signaling properties that may affect their immunogenicity, AAPS J. 21 (2019) 62.

[190] J.T. Andersen, M.B. Daba, I. Sandlie, FcRn binding properties of an abnormal truncated analbuminemic albumin variant, Clin Biochem. 43 (2010) 367-372.

[191] A.R. Mezo, S.C. Low, T. Hoehn, H. Palmieri, PEGylation enhances the therapeutic potential of peptide antagonists of the neonatal Fc receptor, FcRn, Bioorg Med Chem Lett. 21 (2011) 63326335.

[192] H.H. Peter, H.D. Ochs, C. Cunningham-Rundles, D.C. Vinh, P. Kiessling, B. Greve, S. Jolles, Targeting FcRn for immunomodulation: Benefits, risks, and practical considerations, J Allergy Clin Immunol. 146 (2020) 479-491 e475.

[193] A.W. Zuercher, R. Spirig, A. Baz Morelli, T. Rowe, F. Kasermann, Next-generation Fc receptor-targeting biologics for autoimmune diseases, Autoimmun Rev. 18 (2019) 102366.

[194] K.L. Gable, J.T. Guptill, Antagonism of the neonatal Fc receptor as an emerging treatment for myasthenia gravis, Front Immunol. 10 (2019) 3052.

[195] J.T. Sockolosky, M.R. Tiffany, F.C. Szoka, Engineering neonatal Fc receptor-mediated recycling and transcytosis in recombinant proteins by short terminal peptide extensions, Proc Natl Acad Sci USA. 109 (2012) 16095-16100.

[196] A. Datta-Mannan, J. Boyles, L. Huang, Z.Y. Jin, A. Peariso, A.T. Murphy, B. Ellis, N. Douglass, F. Norouziyan-Cooper, D.R. Witcher, Engineered FcRn binding fusion peptides significantly enhance the half-life of a Fab domain in cynomolgus monkeys, Biotechnol J. 14 (2019) e1800007. [197] P.A. Nygren, Alternative binding proteins: affibody binding proteins developed from a small three-helix bundle scaffold, FEBS J. 275 (2008) 2668-2676.

[198] J.T. Andersen, R. Pehrson, V. Tolmachev, M.B. Daba, L. Abrahmsen, C. Ekblad, Extending half-life by indirect targeting of the neonatal Fc receptor (FcRn) using a minimal albumin binding domain, J Biol Chem. 286 (2011) 5234-5241.

[199] J. Seijsing, S. Yu, F.Y. Frejd, I. Hoiden-Guthenberg, T. Graslund, In vivo depletion of serum IgG by an affibody molecule binding the neonatal Fc receptor, Sci Rep. 8 (2018) 5141. 
[200] J. Nilsen, M. Bern, K.M.K. Sand, A. Grevys, B. Dalhus, I. Sandlie, J.T. Andersen, Human and mouse albumin bind their respective neonatal Fc receptors differently, Sci Rep. 8 (2018) 14648. [201] S. Latvala, B. Jacobsen, M.B. Otteneder, A. Herrmann, S. Kronenberg, Distribution of FcRn across species and tissues, J Histochem Cytochem. 65 (2017) 321-333.

[202] J.P. Martins, P.J. Kennedy, H.A. Santos, C. Barrias, B. Sarmento, A comprehensive review of the neonatal Fc receptor and its application in drug delivery, Pharmacol Ther. 161 (2016) 2239.

[203] M. Firan, R. Bawdon, C. Radu, R.J. Ober, D. Eaken, F. Antohe, V. Ghetie, E.S. Ward, The MHC class I-related receptor, FcRn, plays an essential role in the maternofetal transfer of gamma-globulin in humans, Int Immunol. 13 (2001) 993-1002.

[204] S. Roy, T. Nanovskaya, S. Patrikeeva, E. Cochran, V. Parge, J. Guess, J. Schaeck, A. Choudhury, M. Ahmed, L.E. Ling, M281, an anti-FcRn antibody, inhibits IgG transfer in a human ex vivo placental perfusion model, Am J Obstet Gynecol. 220 (2019) 498 e491-498 e499.

[205] E.J. Israel, V.K. Patel, S.F. Taylor, A. Marshak-Rothstein, N.E. Simister, Requirement for a beta 2-microglobulin-associated Fc receptor for acquisition of maternal IgG by fetal and neonatal mice, J Immunol. 154 (1995) 6246-6251.

[206] M.G. Martin, S.V. Wu, J.H. Walsh, Ontogenetic development and distribution of antibody transport and Fc receptor mRNA expression in rat intestine, Dig Dis Sci. 42 (1997) 1062-1069.

[207] E.J. Israel, S. Taylor, Z. Wu, E. Mizoguchi, R.S. Blumberg, A. Bhan, N.E. Simister, Expression of the neonatal Fc receptor, FcRn, on human intestinal epithelial cells, Immunology. 92 (1997) 69-74.

[208] P.R. Cooper, C.M. Kliwinski, R.A. Perkinson, E. Ragwan, J.R. Mabus, G.D. Powers, H. Dorai, J. Giles-Komar, P.J. Hornby, The contribution of cell surface FcRn in monoclonal antibody serum uptake from the intestine in suckling rat pups, Front Pharmacol. 5 (2014) 225.

[209] C. Kliwinski, P.R. Cooper, R. Perkinson, J.R. Mabus, S.H. Tam, T.M. Wilkinson, J. GilesKomar, B. Scallon, G.D. Powers, P.J. Hornby, Contribution of FcRn binding to intestinal uptake of IgG in suckling rat pups and human FcRn-transgenic mice, Am J Physiol Gastrointest Liver Physiol. 304 (2013) G262-270.

[210] U. Shah, B.L. Dickinson, R.S. Blumberg, N.E. Simister, W.I. Lencer, W.A. Walker, Distribution of the IgG Fc receptor, FcRn, in the human fetal intestine, Pediatr Res. 53 (2003) 295-301.

[211] C.M. Story, J.E. Mikulska, N.E. Simister, A major histocompatibility complex class I-like Fc receptor cloned from human placenta: Possible role in transfer of immunoglobulin $\mathrm{G}$ from mother to fetus, J Exp Med. 180 (1994) 2377-2381. 
[212] J.T. Andersen, M.B. Daba, G. Berntzen, T.E. Michaelsen, I. Sandlie, Cross-species binding analyses of mouse and human neonatal Fc receptor show dramatic differences in immunoglobulin G and albumin binding, J Biol Chem. 285 (2010) 4826-4836.

[213] R.J. Ober, C.G. Radu, V. Ghetie, E.S. Ward, Differences in promiscuity for antibody-FcRn interactions across species: implications for therapeutic antibodies, Int Immunol. 13 (2001) 1551-1559.

[214] C. Vaccaro, R. Bawdon, S. Wanjie, R.J. Ober, E.S. Ward, Divergent activities of an engineered antibody in murine and human systems have implications for therapeutic antibodies, Proc Natl Acad Sci USA. 103 (2006) 18709-18714.

[215] J.T. Andersen, J. Cameron, A. Plumridge, L. Evans, D. Sleep, I. Sandlie, Single-chain variable fragment albumin fusions bind the neonatal $F c$ receptor ( $F \subset R n)$ in a species-dependent manner: implications for in vivo half-life evaluation of albumin fusion therapeutics, J Biol Chem. 288 (2013) 24277-24285.

[216] D. Viuff, F. Antunes, L. Evans, J. Cameron, H. Dyrnesli, B. Thue Ravn, M. Stougaard, K. Thiam, B. Andersen, S. Kjaerulff, K.A. Howard, Generation of a double transgenic humanized neonatal Fc receptor $(\mathrm{FcRn}) /$ albumin mouse to study the pharmacokinetics of albumin-linked drugs, J Control Release. 223 (2016) 22-30.

[217] J. Zhou, J.E. Johnson, V. Ghetie, R.J. Ober, E. Sally Ward, Generation of mutated variants of the human form of the MHC class I-related receptor, FcRn, with increased affinity for mouse immunoglobulin G, J Mol Biol. 332 (2003) 901-913.

[218] J. Zhou, F. Mateos, R.J. Ober, E.S. Ward, Conferring the binding properties of the mouse MHC class I-related receptor, FcRn, onto the human ortholog by sequential rounds of sitedirected mutagenesis, J Mol Biol. 345 (2005) 1071-1081.

[219] B.E. Low, G.J. Christianson, E. Lowell, W. Qin, M.V. Wiles, Functional humanization of immunoglobulin heavy constant gamma 1 Fc domain human FCGRT transgenic mice, MAbs. 12 (2020) 1829334.

[220] D.C. Roopenian, G.J. Christianson, G. Proetzel, T.J. Sproule, Human FcRn transgenic mice for pharmacokinetic evaluation of therapeutic antibodies, Methods Mol Biol. 1438 (2016) 103114.

[221] D.C. Roopenian, B.E. Low, G.J. Christianson, G. Proetzel, T.J. Sproule, M.V. Wiles, Albumindeficient mouse models for studying metabolism of human albumin and pharmacokinetics of albumin-based drugs, MAbs. 7 (2015) 344-351.

[222] G. Proetzel, D.C. Roopenian, Humanized FcRn mouse models for evaluating pharmacokinetics of human IgG antibodies, Methods. 65 (2014) 148-153. 
[223] J. Nilsen, I. Sandlie, D.C. Roopenian, J.T. Andersen, Animal models for evaluation of albumin-based therapeutics, Cur Opin Chem Eng. 19 (2018) 68-76.

[224] Y.Y. Fan, H. Neubert, Quantitative analysis of human neonatal Fc receptor (FcRn) tissue expression in transgenic mice by online peptide immuno-affinity LC-HRMS, Anal Chem. 88 (2016) 4239-4247.

[225] C. Stein, L. Kling, G. Proetzel, D.C. Roopenian, M.H. de Angelis, E. Wolf, B. Rathkolb, Clinical chemistry of human FcRn transgenic mice, Mamm Genome. 23 (2012) 259-269.

[226] S.H. Tam, S.G. McCarthy, K. Brosnan, K.M. Goldberg, B.J. Scallon, Correlations between pharmacokinetics of IgG antibodies in primates vs. FcRn-transgenic mice reveal a rodent model with predictive capabilities, MAbs. 5 (2013) 397-405.

[227] C.H. Lee, T.H. Kang, O. Godon, M. Watanabe, G. Delidakis, C.M. Gillis, D. Sterlin, D. Hardy, M. Cogne, L.E. Macdonald, A.J. Murphy, N. Tu, J. Lee, J.R. McDaniel, E. Makowski, P.M. Tessier, A.S. Meyer, P. Bruhns, G. Georgiou, An engineered human Fc domain that behaves like a pHtoggle switch for ultra-long circulation persistence, Nat Commun. 10 (2019) 5031.

[228] N. Shrestha, F. Araujo, M.A. Shahbazi, E. Makila, M.J. Gomes, M. Airavaara, E.I. Kauppinen, J. Raula, J. Salonen, J. Hirvonen, B. Sarmento, H.A. Santos, Oral hypoglycaemic effect of GLP-1 and DPP4 inhibitor based nanocomposites in a diabetic animal model, J Control Release. 232 (2016) 113-119.

[229] Z. Zhang, H. Shan, L. Chen, C. He, X. Zhuang, X. Chen, Synthesis of pH-responsive starch nanoparticles grafted poly (I-glutamic acid) for insulin controlled release, Eur Polym J. 49 (2013) 2082-2091.

[230] M. Cui, W. Wu, L. Hovgaard, Y. Lu, D. Chen, J. Qi, Liposomes containing cholesterol analogues of botanical origin as drug delivery systems to enhance the oral absorption of insulin, Int J Pharm. 489 (2015) 277-284.

[231] C. Azevedo, M.H. Macedo, B. Sarmento, Strategies for the enhanced intracellular delivery of nanomaterials, Drug Discov Today, 23, 944-959 (2018).

[232] Q. Xu, L.M. Ensign, N.J. Boylan, A. Schon, X. Gong, J.C. Yang, N.W. Lamb, S. Cai, T. Yu, E. Freire, J. Hanes, Impact of surface polyethylene glycol (PEG) density on biodegradable nanoparticle transport in mucus ex vivo and distribution in vivo, ACS Nano. 9 (2015) 9217-9227. [233] M.J. Mitchell, M.M. Billingsley, R.M. Haley, M.E. Wechsler, N.A. Peppas, R. Langer, Engineering precision nanoparticles for drug delivery, Nat Rev Drug Discov. (2020).

[234] I. Khan, K. Saeed, I. Khan, Nanoparticles: Properties, applications and toxicities, Arab J Chem. 12 (2019) 908-931. 
[235] J.P. Oliveira, A.R. Prado, W.J. Keijok, P.W.P. Antunes, E.R. Yapuchura, M.C.C. Guimaraes, Impact of conjugation strategies for targeting of antibodies in gold nanoparticles for ultrasensitive detection of 17beta-estradiol, Sci Rep. 9 (2019) 13859.

[236] K. Werengowska-Ciećwierz, M. Wiśniewski, A.P. Terzyk, S. Furmaniak, The chemistry of bioconjugation in nanoparticles-based drug delivery system, Adv Condens Matter Phys. 2015 (2015) 1-27.

[237] J. Ravasco, H. Faustino, A. Trindade, P.M.P. Gois, Bioconjugation with maleimides: A useful tool for chemical biology, Chemistry. 25 (2019) 43-59.

[238] D. Bartczak, A.G. Kanaras, Preparation of peptide-functionalized gold nanoparticles using one pot EDC/Sulfo-NHS coupling, Langmuir. 27 (2011) 10119-10123.

[239] S. Keleştemur, M. Altunbek, M. Culha, Influence of EDC/NHS coupling chemistry on stability and cytotoxicity of ZnO nanoparticles modified with proteins, Appl Surf Sci. 403 (2017) 455-463.

[240] M. Lopes, A. Derenne, C. Pereira, F. Veiga, R. Seica, B. Sarmento, A. Ribeiro, Impact of the in vitro gastrointestinal passage of biopolymer-based nanoparticles on insulin absorption, RSC Adv. 6 (2016) 20155-20165.

[241] M.G.E.G. Bremer, J. Duval, W. Norde, J. Lyklema, Electrostatic interactions between immunoglobulin (IgG) molecules and a charged sorbent, Colloids Surf A Physicochem Eng Asp. 250 (2004) 29-42.

[242] A. Awaad, M. Nakamura, K. Ishimura, Imaging of size-dependent uptake and identification of novel pathways in mouse Peyer's patches using fluorescent organosilica particles, Nanomedicine. 8 (2012) 627-636.

[243] M.P. Desai, V. Labhasetwar, G.L. Amidon, R.J. Levy, Gastrointestinal uptake of biodegradable microparticles: effect of particle size, Pharm Res. 13 (1996) 1838-1845.

[244] L.S. Arias, J.P. Pessan, A.P.M. Vieira, T.M.T. Lima, A.C.B. Delbem, D.R. Monteiro, Iron oxide nanoparticles for biomedical applications: A perspective on synthesis, drugs, antimicrobial activity, and toxicity, Antibiotics. 7 (2018).

[245] B.B. Manshian, J. Jimenez, U. Himmelreich, S.J. Soenen, Personalized medicine and followup of therapeutic delivery through exploitation of quantum dot toxicity, Biomaterials. 127 (2017) $1-12$.

[246] O.K. Nag, J.B. Delehanty, Active cellular and subcellular targeting of nanoparticles for drug delivery, Pharmaceutics. 11 (2019).

[247] S. Mansoor, P.P.D. Kondiah, Y.E. Choonara, V. Pillay, Polymer-based nanoparticle strategies for insulin delivery, Polymers. 11 (2019). 


\section{Highlights}

- The symptomatology of diabetes must be controlled to prevent fibrosis development.

- FcRn is responsible for the efficient transcytosis and half-life extension of drugs.

- Engineered FcRn-targeted ligands are a strategy to enhance receptor-binding affinity.

- FcRn-targeting nanosystems can improve antidiabetic peptides' oral bioavailability. 